\title{
Umělecký text v didaktickém aparátu čítanek pro primární školy: výsledky analýzy ${ }^{1}$
}

\author{
Hana Lavičková \\ Masarykova univerzita, Pedagogická fakulta, Katedra českého jazyka a literatury
}

Redakci zasláno 18. 8. 2014 / upravená verze obdržena 9. 1. 2015 / k uveřejnění přijato 26. 1. 2015

\begin{abstract}
Abstrakt: Cílem empirické studie je představit výsledky obsahové analýzy podob zadání didaktického aparátu čítanek určených pro žáky primární školy z hlediska jeho směřování $\mathrm{k}$ naplnění přímé práce žáků s uměleckými texty zařazenými do čítanek. V první části studie poukazujeme na specifickou roli čítanek při rozvíjení estetickovýchovného pojetí školní literární výchovy. Druhá část je věnována literárněvědným, literárnědidaktickým a kurikulárním východiskủm výzkumu. Třetí část popisuje současný stav poznání v oblasti výzkumu čítanek. Ve čtvrté části představujeme metodologii výzkumu; výzkumný vzorek tvořil didaktický aparát 2 ucelených čítankových řad (8 čítanek určených pro 2.-5. ročník primární školy) sestávající z 3450 otázek, úkolů a námětů k činnostem. V páté části prezentujeme výsledky výzkumu, které poukázaly na některé společné tendence a výrazné rozdíly mezi zkoumanými čítankami. Zjistili jsme, že na práci žáků s uměleckým textem se nejvýrazněji orientují didaktické aparáty čítanek pro 4. a 5. ročník primární školy, nejméně didaktické aparáty čítanek pro 2 . ročník primární školy. $Z$ výsledků vyplývá, že zastoupení jednotlivých oblastí uměleckého textu je ve zkoumaných čítankách značně nerozmanité. $V$ didaktickém aparátu čítanek převažují otázky, úkoly a náměty $\mathrm{k}$ činnostem zaměřené na tematiku a smysl uměleckého textu. Na základě zjištěných výsledků předkládáme v závěru studie doporučení pro tvorbu čítanek.
\end{abstract}

Klíčová slova: umělecký text, literární výchova, primární škola, čítanka, didaktický aparát čítanek, obsahová analýza

Za tradičního prostředníka mezi uměleckými texty ${ }^{2}$ tvořícími vlastní obsah literárního vzdělávání a jejich recipienty (žáky) se ve školní praxi považuje

1 Vznik studie byl podpořen z projektu Kurikulum základní školy: metodologické př́stupy a empirická zjištění (MUNI/A/0813/2013).

2 Umělecký text chápeme jako osobitý, neopakovatelný multifunkční celek (Plch, 1981, s. 25), jehož svébytné postavení $\mathrm{v}$ rámci ostatních komunikátů psané povahy spočívá zejména v jeho estetické funkci a hodnotě (viz Mukařovský, 1966). Ve školní literární výchově reprezentuje kvalitu učiva i umění (Lederbuchová, 2001, s. 83) a stává se tak specifickým fenoménem, který „,hluboce zasahuje individualitu recipienta, interpreta i zprostředkovatele interpretačních činností" (Vařejková, 1998, s. 11). 
čítanka. Tato specifická učebnice literární výchovy pojímaná jako reprezentativní antologie uměleckých textů se stává významným zprostředkovatelem komunikace žáka s extensionálními a intensionálními ${ }^{3}$ dimenzemi uměleckého textu, a to nejen výběrem a uspořádáním textů, ale i jejich reflexí zprostředkovanou svým didaktickým aparátem ${ }^{4}$. Výlučné postavení čítanek mezi ostatními učebnicemi spočívá v jejich nezastupitelné roli prostředníka mezi uměleckými texty a žáky, z čehož vyplývá i jejich specifická funkce spočívající ve zkvalitňování žákovy čtenářské/literární gramotnosti ${ }^{5}$.

Empiricky podložená evaluace čítanek je však (nejen) v českém prostředí velmi okrajovou záležitostí (srov. Ruebsamen \& Erner, 1993, s. 57-60). Přesto jsme přesvědčeni o její potřebnosti a významu v souvislosti se sílícími diskusemi didaktiků literární výchovy o současné koncepci literárního vzdělávání, kdy autority oboru upozorňují zejména na skutečnost, že si literární výchova doposud plně nevydobyla status estetickovýchovného předmětu jak v kurikulárních dokumentech, tak ve školní praxi (podrobněji viz Hník, 2010, s. 153). Pro smysluplnou školní literární výchovu považujeme za žádoucí, aby podoby zadání otázek, úkolů a námětů k činnostem tvořících didaktický aparát čítanek směřovaly $\mathrm{k}$ naplnění přímé práce žáků s uměleckými texty zařazenými do čítanek, a tím přispěly k rozvíjení estetickovýchovného zaměření předmětu literární výchova v primární škole. Cílem prezentované studie je charakterizovat didaktický aparát čítanek dvou ucelených čítankových řad určených pro žáky primární školy z hlediska jeho zaměření na přímou práci žáků s uměleckým textem, na mezipředmětové propojení literární výchovy s ostatními školními předměty, na literární kontext nevycházející z recepce uměleckého textu a mimotextovost reprezentující odklon didaktického aparátu čítanek od uměleckého textu.

3 Extensionální rovinu chápeme jako rozsah pojmu, jako denotaci výrazu ve smyslu významů, k nimž výraz odkazuje v reálném světě. Intensinonální rovina je pak obsahem daného pojmu, jeho smyslem v konkrétním užití (blíže viz Doležel, 2004; Müller \& Šidák, 2012).

4 Didaktickým aparátem čítanek rozumíme otázky, úkoly a náměty k činnostem určené pro přímou práci žáků s texty umělecké literatury uvedenými v čítankách.

5 Termíny čtenářská gramotnost a literární gramotnost byly do českého prostředí zavedeny v 90. letech 20. století (blíže viz Rabušicová, 2002; Wildová, 2012) v souvislosti se zapojením České republiky do mezinárodních výzkumných projektů měřicích různé úrovně gramotností. Čtenářskou gramotnost pojímáme podle definice VÚP $(2011$, s. 10) jako „celoživotně se rozvíjející vybavenost člověka vědomostmi, dovednostmi, schopnostmi, postoji a hodnotami potřebnými pro užívání všech druhů textů v různých individuálních i sociálních kontextech“. Literární gramotnost chápeme jako schopnost poučené recepce uměleckého textu vycházející z porozumění specifikům uměleckých textů jako „komunikátů, jejichž podstatou je ambivalentnost a mnohovýznamovost“ (Zachová, 2012, s. 96). 


\section{Východiska výzkumu}

Kapitola je věnována teoretickým a empirickým východiskům výzkumu, které se vztahují k uměleckému textu jako vlastnímu obsahu literárního vzdělávání. Nejprve se zabýváme literárněvědnými a literárnědidaktickými východisky. Poté se zaměřujeme na kurikulární a následně na empirická východiska výzkumu.

\subsection{Literárněvědná a literárnědidaktická východiska}

Školní literární výchova se odvíjí od uměleckého textu a jeho interpretace (Vařejková, 1998), od čtenářského zážitku nebo zážitku z tvorby (srov. Slavík, 1997, 2001, 2011). Na umělecký text, který je v české, slovenské (ale i světové) literární didaktice považován za vlastní obsah literární výchovy, se odvolává většina teoretiků i praktiků literárního vzdělávání (Germušková, 2003; Ligoš, 2009; Hník, 2010). V kontextu postmoderní plurality literární vědy je na umělecký text možné nahlížet z nejrůznějších hledisek (blíže viz Haman, 2012; Macura \& Jedličková, 2012). Pro účely našeho výzkumu považujeme za nejpřiléhavější (vzhledem k zaměření výzkumu na didaktický aparát čítanek určený žákům primární školy a rozmanitý charakter současných čítanek) tradiční strukturalistický přístup k uměleckému textu (podrobněji viz Doležel, 2000). Ten se pro nás v pojetí strukturalistické školy L. Doležela (2004) stává východiskem pro analytickou část výzkumu, jelikož nám umožňuje odlišovat primárně estetickou funkci ${ }^{6}$ literárního textu od jeho mimoestetických přesahů7. Strukturalisticky pojatá literárněvědná metodologie nabízí pro účely našeho výzkumu sémantický přístup k analýze didaktického aparátu čítanek demonstrovaný odlišením extensionálních a intensionálních dimenzí fikčního světa literárního díla, z jehož svébytnosti vyplývá nejen (pro školní literární výchovu) nezbytný požadavek neredukování uměleckého textu na služebníka mimoestetických funkcí.

Celková koncepce našeho výzkumu a jeho možná aplikace do praxe je teoreticky zastřešena fenomenologicky orientovanou koncepcí estetického zážitku. Hovoříme-li o estetickém zážitku v literárněvýchovném procesu, máme na mysli zážitek pramenící z přímého kontaktu žáka se slovesným

6 V literatuře, tak jak ji chápe moderní doba, je estetická funkce textu založena na potlačování praktických funkcí a estetická hodnota se odvíjí od oceňování mnohoznačnosti, nestanovitelnosti definitivního významu.

7 Mimoestetické přesahy pojímáme v intencích požadavků RVP ZV (2007) na mezioborové propojení školních vzdělávacích předmětů. 
uměleckým dílem, který můžeme ( $\mathrm{v}$ analogii $\mathrm{s}$ výtvarným uměním) pojímat prostřednictvím čtyř úrovní, jak uvádí Slavík (2001, s. 255-264), a to prostřednictvím:

(a) významu, který nám říká, CO dílo zobrazuje, či k čemu se vztahuje; (b) konstrukce, která odpovídá na otázku, JAK a jakými prostředky bylo dílo zobrazeno; (c) empatie, tedy jak divákovo vnímání obrazu koresponduje $\mathrm{s}$ původním záměrem autora (tato úroveň je také důležitá při sociálním vyjednávání významu pojímání obrazu různými recipienty); a konečně se jedná o úroveň; (d) prožitku, který je ve své podstatě nepřenositelný a může být pouze popsán nebo zprostředkován různými typy vyjádření jako napřs slovy, tancem atd.

Na otázku „CO literární text obsahuje?" můžeme hledat odpovědi jak v diskursu literárněvědného strukturalizmu ve smyslu formulování námětu a dalších vedlejších myšlenek díla, tak v postmoderních polohách literární vědy ve smyslu převyprávění extensionálního obsahu textu. Otázka „JAK a jakými prostředky bylo dílo zobrazeno?" však již bezprostředně souvisí s rekonstrukcí intensionální složky textu vycházející z expresivního zážitku ze slovesného uměleckého díla. Za zjištěním, jak text mluví, je skryta re-konstrukce jeho intensionálního obsahu, který je nutné př́imo zažít v aktu čtení či poslechu. Intensionální obsah uměleckého textu je tedy nejúžeji spjat s estetickou funkcí uměleckého textu a s jeho expresivními vlastnostmi. Slavíkem zmiňovanou empatii a prožitek vycházející z žákovy bezprostřední zkušenosti s uměleckým textem pak rovněž nelze zaměnit popisem jeho obsahu, tj. zkušeností zprostředkovanou. J. Searle (1985, podle Slavíka, 2001) tento problém vysvětluje jako nemožnost redukovat poznávání z pozice ontologie první osoby na poznávání z pozice ontologie třetí osoby. Jak uvádí Vařejková (1998, s. 13), „umělecké dílo je předmětem práce v literární výchově, proto je v procesu výuky dominantní složkou, určuje cíl činnosti, její obsah i metodické postupy“. Školní literární výchova vystavěná na expresivním zážitku z uměleckého textu, která požaduje tvůrčí práci s tvůrčí materií uměleckého díla tedy s intensionální složkou uměleckého textu, pak v procesu uměleckého utváření a/nebo rekonstruování uměleckého textu nabývá kvalit estetickovýchovně zaměřeného předmětu s expresivně tvořivým charakterem.

Propojení paradigmat literárněvědného strukturalismu v současném pojetí Doleželovy školy s fenomenologicky orientovanou koncepcí estetického zážitku a jeho reflektivní analýzou v oborové didaktice literární výchovy směřuje k poučené recepci uměleckého textu vycházející z čtenářského zážitku. 
Žák by tedy (při důrazu na intensionální funkci) měl tvořivě re-konstruovat čili aktivně interpretovat nejen entity fikčního světa díla a jejich strukturu, ale i způsob výstavby intensionálních významů zakotvených $\mathrm{v}$ textuře díla (Červenka, 2003). Za zjištěním „jak text mluví" se tedy skrývá proces rekonstrukce intensionální (neparafrázovatelné) významové struktury uměleckého textu, což lze uskutečnit pouze za předpokladu přímého čtenářského zážitku.

Základní kategorie imanentní textové roviny vymezujeme pro účely našeho výzkumu podle literárně-teoretické práce Peterky (2009). Autor zde stanovil literárně-teoretické koncepty a jejich didaktické přesahy vymezující vlastní roviny slovesného uměleckého díla založené na jeho estetické funkci. Definování textových oblastí obsahově zúžených ve vztahu k očekávaným výstupům literárního vzdělávání žáků primární školy tvoří základní strukturu našeho výzkumného nástroje - kategoriálního systému.

\subsection{Kurikulární východiska}

V souvislosti s požadavky Rámcového vzdělávacího programu pro základní vzdělávání (dále RVP ZV) na mezioborové propojení vzdělávacích obsahů zařazujeme do našeho výzkumu oblast Kontexty. Kontexty chápané jako souvislosti a podmínky spjaté s obsahovým zaměřením konkrétního úkolu či otázky zařazené do čítanky (srov. Průcha et al., 2013, s. 133) pak vydělujeme do dvou oblastí (Kontext se sekundární estetickou funkcí; Kontext mimoestetic$k y ́$ ), a to na základě jejich vztahu k uměleckému textu jako jejich východisku. Kontext se sekundární estetickou funkcí, kterou pojímáme ve smyslu obsahového zaměření na extensionální (čili parafrázovatelnou) dimenzi uměleckého textu, recipuje umělecký text $\mathrm{v}$ těsném sepětí $\mathrm{s}$ mimooborovými přesahy týkajícími se neliterárních školních vyučovacích předmětů (českého jazyka, matematiky, našeho světa [1.-3. ročník primární školy], přírodovědy, vlastivědy, výtvarné výchovy, hudební výchovy, tělesné výchovy). Oblast Kontext mimoestetický chápeme jako obsahové naplnění školní literární výchovy literárněhistorickými, terminologickými a biografickými poznatky, které však nevycházejí z přímé práce žáků s uměleckým textem (ten zde neplní ani dokládající, ani zprostředkující funkci). Poznatky se sice váží k literární výchově, ale reprezentují spíše formalistický prrístup k literatuře než estetickovýchovné pojetí literárního vzdělávání. 
Literární výchova svou povahou estetickovýchovného školního předmětu pracujícího s uměleckými texty nejrůznějšího tematického zaměření př́ímo vybízí k uplatňování širokých mezioborových přesahů. Otázkou však zůstává, zda tyto mimooborové přesahy reflektují literární př́stup ${ }^{8} \mathrm{k}$ uměleckému dílu. Neliterární přístup k uměleckému textu zařazenému do čítanek pojímáme v našem výzkumu ve shodě s Hrabákem $(1977$, s. 21) jako „prostředek sloužící k ilustraci jiných učebních předmětü" a vyčleňujeme jej do oblasti Mimotextovost. Mimotextovost (situovanost) chápeme podle Peterky (2009, s. 47) jako odklon od fikčního světa uměleckého textu. Zařazení mimotextovosti do našeho výzkumu vychází z kurikulárních požadavků na uplatňování komplexní vize vzdělávání s centrem v širokém mezioborovém propojení směřujících k získávání nadpředmětových obecně využitelných dovedností, které umožňují člověku rychle se adaptovat na neustále se měnící podmínky vnějšího prostředí a efektivně a kriticky třídit a zpracovávat informace specifikované pro konkrétní účely. Oblast Mimotextovost reprezentuje směřování tematiky otázek a úkolů zařazených do čítanek k naplnění vzdělávacího obsahu neliterárních vyučovacích předmětů.

\subsection{Empirická východiska}

Pro samotný metodický postup vedoucí k posuzování a hodnocení kvality čítanek z hlediska směřování jejich didaktického aparátu k naplnění př́ímé práce $\mathrm{s}$ uměleckým textem a $\mathrm{k}$ závěrečné interpretaci zjištěných výsledků jsme jako východiska zvolili empirické studie německých autorů, a to vzhledem k relativně blízkému pojetí literárního vzdělávání, dlouholeté výzkumné tradici i kontinuálnímu průběhu výzkumu čítanek.

Helmers (1969) provedl obsahovou analýzu německých čítanek, na základě které porovnával, jak do učebnic literatury pronikají literárně-sociologické aspekty. Navrhl rozsáhlý kategoriální systém, v jehož intencích prezentoval jednotlivá literárně-sociologická kritéria a jejich průniky do celkové podoby čítanek ve smyslu výběru a řazení textů i jejich doprovodných úkolů. Pro potřeby našeho výzkumu jsme se inspirovali zejména pojetím úkolů $\mathrm{k}$ jednotlivým textům zařazeným do čítanek a jejich didaktickým zpracováním pro žáky.

Literární přístup k uměleckému textu vychází ze specifických rysů uměleckých textů (subjektivnost, používání aktualizovaného jazyka, fiktivnost, intertextovost), na jejichž pozadí se vyděluje literární (umělecká) slovesnost od textů neliterárního charakteru (primárně věcné povahy). 
Rozsáhlou empirickou studii postihující vývoj čítanek v Německu a jejich současné směřování předložila Wildeová et al. (2000). Metodou obsahové analýzy vycházející z požadavků historického vývoje výuky literatury na německých školách a rozvoje čtenářství žáků byla stanovena kritéria pro analýzu čítanek z hlediska požadavků na rozvíjení čtenářské kompetence, mezi něž jsou řazeny např. kategorie struktury textu, výběr a počet textů, intertextovost, komentáře $\mathrm{k}$ jednotlivým textům, otázky a úkoly k textům, celková typografie aj. Kategoriální systém Wildeové nám byl metodologickou oporou z hlediska vymezení kategorie struktury uměleckého textu.

Indikátory rozvoje čtenářské kompetence $\mathrm{v}$ učebnicích německého jazyka navrhla Hoppeová (2011), jež v empirické studii analyzovala jednotlivé úlohy v učebnicích německého jazyka žáků 4. ročníku s ohledem na jejich přínos ke vzdělávání a důrazem na rozvoj čtenářství. Bylo zjištěno, že největší podíl v čítankách zaujímají úlohy zaměřené na hledání informací z textu (40-50 \%), následují úlohy interpretační (10-30 \%) a úlohy zaměřené na porozumění textu (7-20\%). S nejnižší četností byly zastoupeny otázky směřující k dekódování významů čteného (5-15 \%). Výsledky tohoto výzkumu nám poskytly zpětnou vazbu $\mathrm{k}$ námi provedené analýze $\mathrm{v}$ oblasti zaměření didaktického aparátu čítanek na interpretaci uměleckého textu.

\section{Dosavadní stav poznání}

Zabýváme-li se literárnědidaktickou či pedagogickou reflexí současných českých čítanek, nezbývá než konstatovat, že stojí spíše stranou odborného zájmu. Kontinuálně se evaluaci čítanek pro primární školu věnuje Zítková (2005-2013). Zítková (2005) analyzovala čítanky pro 4. a 5. ročníky základní školy, přičemž zhodnotila stav čítankové tvorby od roku 1990 do roku 2005 z hlediska využívání jednotlivých učebnic v pedagogické praxi. Dospěla k závěru, že nejužívanějšími čítankami ve sledovaných ročnících primární školy ve sledovaném období byly čítanky nakladatelství Alter. Výzkum rovněž posuzoval kritéria souladu čítanek s požadavky na cíle a obsah literárního vyučování ve 4. a 5. ročnících ZŠ, a to v kontextu s kodifikovanými kurikulárními dokumenty té doby (Standard základního vzdělávání a z vzdělávacích programů zejména program Základní škola). Formativní vliv literární výchovy byl zúžen na otázku hodnotové preference v literárních ukázkách, kde bylo jako nejfrekventovanější prokázáno zastoupení tematiky mezilidských vztahů a prŕrody. 
Čítanky pro druhý stupeň základních škol a střední školy jsou rovněž reflektovány sporadicky (Pokorná, 2003; Lederbuchová 2003-2004; Hník, 2010). Lederbuchová (2003-2004) analyzovala čítanky pro 6. ročník základní školy z hlediska kritérií jejich kvality. Autorka došla ke zjištění, že se pojetí ćítanek pro 6. ročník různí podle toho, které funkce literární výchovy autoři čítanek preferují. Čítanky pak na základě výsledků obsahové analýzy rozdělila do tří kategorií - na čítanky zájmově čtenářské, vzdělávací a výchovné.

\section{Metodologie výzkumu}

Předmětem našeho výzkumu byl didaktický aparát čítanek, za nějž považujeme konkrétní podoby zadání otázek, úkolů a námětů k činnostem zařazených do čítanek uvedených před textem ${ }^{9}$ - jako jeho uvedení, či za textem jako jeho reflektování, které jsou určeny pro přímou práci žáků a vztahují se $\mathrm{k}$ uměleckému textu ${ }^{10}$ zařazenému do čítanky (srov. Lederbuchová, 2008, s. 82). Didaktický aparát čítanek svým pojetím prostředníka mezi žákem a uměleckým textem organizuje recepční činnosti žáků v určitých obsahových (literárních i mimooborových) rámcích. Jejich konkrétní vymezení a kvalitativní posouzení ve vztahu k vlastnímu obsahu literárního vzdělávání - uměleckému textu - tvoří klíčový metodický prvek naší analýzy. Ta spočívá v kategorizaci didaktického aparátu čítanek do obsahových rámců (kategorií a podkategorií), které by ve školní literární výchově měly být zastoupeny tak, aby výuka literatury směřovala k svému cíli - schopnosti poučené recepce uměleckého textu.

Cílem výzkumu bylo posoudit povahu zadání didaktického aparátu čítanek pro primární školu z hlediska jeho směřování $\mathrm{k}$ naplnění přímé práce žáků s uměleckým textem. K tomuto cíli se vztahují níže uvedené otázky explorativně-komparativního charakteru:

- Do jaké míry se didaktický aparát analyzovaných čítanek vztahuje k uměleckému textu a jaké je zastoupení jednotlivých oblastí jeho struktury?

9 Za text považujeme každý beletristický útvar (konkrétní grafický celek) s vlastním titulem, popř. s uvedením autora, pokud jde o text autorský. Rozsah textů se různí, a to podle dosažené úrovně čtenářství žáků a žánrového zastoupení jednotlivých textů. Rozsah poetických textů se pohybuje v limitech 2-50 veršů. Rozsah prozaických textů kolísá v rozmezí 2000-5000 znaků (srov. Zítková, 2005, s. 70).

10 Otázky, úkoly a náměty k činnostem uvedené v čítankách ve vztahu k textům odborné a věcné literatury předmětem analýzy nebyly, a to vzhledem k zaměření estetickovýchovného pojetí literárního vzdělávání na texty beletristické povahy. 
- Do jaké míry jsou v didaktickém aparátu čítanek zastoupeny otázky/úkoly a náměty $\mathrm{k}$ činnostem směřující $\mathrm{k}$ mezipředmětovému propojení literární výchovy s ostatními školními předměty?

- Do jaké míry se didaktický aparát čítanek orientuje na literárněteoretické, biografické a historické kontexty, které nesouvisejí s textem umělecké povahy zařazeným do čítanky?

- Do jaké míry jsou v didaktickém aparátu čítanek obsaženy otázky, úkoly a náměty $\mathrm{k}$ činnostem sloužící $\mathrm{k}$ ilustraci neliterárních školních předmětů?

Pro účely vlastního výzkumu jsme analyzovali záměrně vybraný vzorek ${ }^{11}$ dvou čítankových řad, jímž rozumíme vždy čtyři na sebe navazujících čítanky určené pro žáky 2.-5. ročníku primární školy vydané v rámci dvou různých nakladatelství, a to z nakladatelství SPN (Čeňková \& Ježková, 2010; Čeňková \& Jonák, 2010; Čeňková \& Jonáková, 2010) a Fraus (Šebesta \& Váňová, 2008-2011).

Ke kategorizaci didaktického aparátu čítanek jsme jako výzkumnou metodu zvolili obsahovou analýzu otázek, úkolů a námětů k činnostem zařazených do čítanek, kterou pojímáme podle Š. Švece (2009, s. 141) jako metodu na rozhraní metod kvalitativních a kvantitativních, při níž se kvantifikace obsahových jednotek (čili konkrétních úkolů, otázek a námětů k činnostem) uskutečňuje v rámci jejich kvalitativních kategorií, tedy pojmů, tematik a myšlenek, které se v našem výzkumu primárně vztahují k naplnění přímé práce žáků s uměleckým textem. Jednotkami obsahové analýzy rozumíme konkrétní otázky, úkoly a náměty $\mathrm{k}$ činnostem uvedené $\mathrm{v}$ čítankách a adresované žákům $(n=3450)$.

Kvantifikace jednotek obsahové analýzy naplňuje povahu smíšeného výzkumného designu, kdy se kvalitativně vymezené kategorie kvantifikují v rámci jednotlivých podkategorií předloženého kategoriálního systému (srov. Carley, 1993, s. 81). Pro účely statistického zpracování získaných dat používáme základní statistické metody, a to určování absolutních a relativních četností a neparametrickou statistiku test dobré shody chí-kvadrát s dodatkem o z-skóre (Chráska, 2007, s. 79-82).

11 Kritéria výběru byla následující: čítanky disponovaly platnou schvalovací doložkou MŠMT ČR; čítanky pocházely ze dvou nakladatelství prezentujících se jako nakladatelství tradičního a inovativního zaměření; čítanky byly adresovány žákům 2., 3., 4. a 5. ročníku primární školy; čítanky byly vydány v souladu s RVP ZV. 


\subsection{Design výzkumu}

Výzkum probíhal ve dvou etapách, jak prezentujeme na obrázku 1. První výzkumná etapa korespondovala s vymezením prvních tří dílčích cílů naší práce směřujících $\mathrm{k}$ vytvoření literárněvědných, literárnědidaktických a kurikulárních konstruktů estetickovýchovné koncepce literárního vzdělávání v primární škole. Tato analytická fáze výzkumu spočívala v operacionalizaci teoretických konstruktů literárního vzdělávání. Jejím cílem bylo vytvoření a ověření výzkumného nástroje. Druhá etapa výzkumu zohledňovala čtvrtý dílčí cíl práce, jelikož spočívala v použití našeho výzkumného nástroje při obsahové analýze didaktického aparátu čítanek pro primární školu. Výsledky této analýzy sloužící k popisu a srovnání zkoumaných čítankových řad směřují k naplnění hlavního cíle našeho výzkumu, jímž je posoudit kvalitu čítanek pro primární školu z hlediska jejich směřování k naplnění estetickovýchovného pojetí literárního vzdělávání v primární škole.

\subsection{Kategoriální systém}

Kategoriální systém (Lavičková, 2012, 2013) je tvořen ze 4 hlavních kategorií: Umělecký text, Kontext se sekundární estetickou funkcí, Kontext mimoestetický, Mimotextovost. Jednotlivé kategorie kategoriálního systému jsou pak detailně rozčleněny do podkategorií, k jejichž obsahové příslušnosti pak přiřazujeme konkrétní otázky, úkoly a náměty k činnostem tvořící didaktický aparát čítanek, a to podle povahy jejich zadání, což ilustrujeme v tabulce 1.

V kategorii Umělecký text chápané jako obsahové naplnění estetickovýchovného pojetí literárního vzdělávání jsme vydělili sedm podkategorií (Jazyk a styl, Žánr, Vypravěč, Kompozice, Téma, Smysl, Intertextovost), jež reprezentují jednotlivé složky uměleckého textu. Při obsahovém vymezování jednotlivých podkategorií jsme se opírali zejména o teoretickou práci Peterky (2009), viz podkapitola 2.1 této práce.

Zařazení kategorií Kontext se sekundání estetickou funkcí, Kontext mimoestetický a Mimotextovost do předkládaného kategoriálního systému vyplynulo z námi provedené obsahové analýzy učiva a očekávaných výstupů vzdělávacího oboru Český jazyk a literatura pro 1. stupeň základního vzdělávání v RVP ZV (Lavičková, 2013, s. 65). Kategorie Kontext, Kontext se sekundární estetickou funkcí a Mimotextovost však reflektují neliterární přístup v čítankách, jelikož pojímají literární výchovu jako prostředek sloužící k ilustraci jiných učebních předmětů (viz Hrabák, 1977, s. 21). 


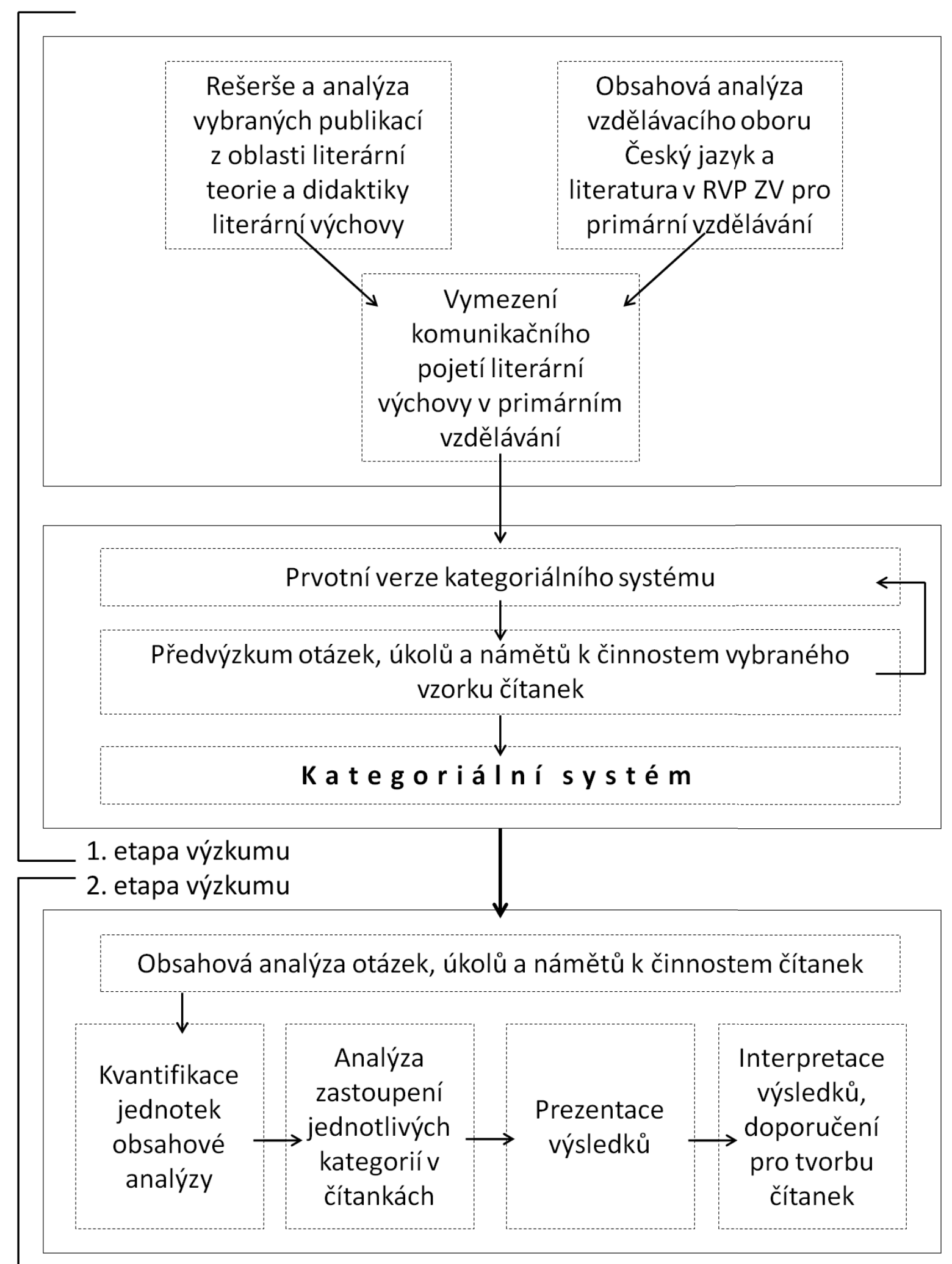

Obrázek 1. Design výzkumu. 
Tabulka 1

Výsledná verze kategoriálního systému

\begin{tabular}{|c|c|c|c|c|}
\hline Kategorie & Podkategorie & Kód & $\begin{array}{l}\text { Obsahové vymezení } \\
\text { podkategorie }\end{array}$ & Příklad \\
\hline \multirow[t]{7}{*}{$\begin{array}{l}\text { Umělecký } \\
\text { text }\end{array}$} & Jazyk a styl & $\mathrm{T} 1$ & $\begin{array}{l}\text { Jazykové prostředky, druhy } \\
\text { řeči, básnické konstrukce, } \\
\text { verš a rytmus, rým a strofa. }\end{array}$ & $\begin{array}{l}\text { Která slova v básni } \\
\text { ukrývají podzim? }\end{array}$ \\
\hline & Žánr & $\mathrm{T} 2$ & $\begin{array}{l}\text { Lyrika, epika, drama, poezie, } \\
\text { próza, folklórní slovesnost. }\end{array}$ & $\begin{array}{l}\text { Má básnička nějaký děj } \\
\text { nebo vyjadřuje spíše } \\
\text { náladu? }\end{array}$ \\
\hline & Vypravěč & T3 & Druhy řeči, typy vypravěčů. & $\begin{array}{l}\text { Kdo příběh vypráví? Čím } \\
\text { se odlišuje promluva } \\
\text { Josífka a vypravěče? }\end{array}$ \\
\hline & Kompozice & $\mathrm{T} 4$ & $\begin{array}{l}\text { Kompozice vnější a vnitřní, } \\
\text { postava, prostor. } \\
\text { Vyprávění chronologické, } \\
\text { retrospektiva. }\end{array}$ & $\begin{array}{l}\text { Kde se příběh odehrává? } \\
\text { Čím se básně odlišují, aniž } \\
\text { byste je předtím četli? }\end{array}$ \\
\hline & Téma & T5 & $\begin{array}{l}\text { Věcný obsah, tematická } \\
\text { výstavba, motivické } \\
\text { komplexy. }\end{array}$ & $\begin{array}{l}\text { O čem si děti povídaly? Co } \\
\text { se Aničce přihodilo? }\end{array}$ \\
\hline & Smysl & T6 & $\begin{array}{l}\text { Explicita, implicita, } \\
\text { interpretace. }\end{array}$ & $\begin{array}{l}\text { Jak se děti v př́iběhu } \\
\text { zachovaly? }\end{array}$ \\
\hline & Intertextovost & T7 & Vztah k pretextu, posttextu. & $\begin{array}{l}\text { Kterou pohádku Vám } \\
\text { vyprávění připomíná? }\end{array}$ \\
\hline \multirow{6}{*}{$\begin{array}{l}\text { Kontext se } \\
\text { sekundární } \\
\text { estetickou } \\
\text { funkcí }\end{array}$} & $\begin{array}{l}\text { Umělecký text } \\
\text { - český jazyk }\end{array}$ & KS1 & $\begin{array}{l}\text { Mezioborové propojení } \\
\text { literární výchovy s českým } \\
\text { jazykem. }\end{array}$ & $\begin{array}{l}\text { Vypiš z ukázky všechna } \\
\text { slovesa. }\end{array}$ \\
\hline & $\begin{array}{l}\text { Umělecký text } \\
\text { - matematika }\end{array}$ & KS2 & $\begin{array}{l}\text { Mezioborové propojení } \\
\text { literární výchovy } \\
\text { s matematikou. }\end{array}$ & $\begin{array}{l}\text { Kolik postav loupežníci } \\
\text { okradli? }\end{array}$ \\
\hline & $\begin{array}{l}\text { Umělecký text } \\
\text { - náš svět }\end{array}$ & KS3 & $\begin{array}{l}\text { Mezioborové propojení } \\
\text { literární výchovy } \\
\text { s prvoukou/přírodovědou/ } \\
\text { vlastivědou. }\end{array}$ & $\begin{array}{l}\text { Z jakých listnatých stromů } \\
\text { už spadlo listí? }\end{array}$ \\
\hline & $\begin{array}{l}\text { Umělecký } \\
\text { text - hudební } \\
\text { výchova }\end{array}$ & KS4 & $\begin{array}{l}\text { Mezioborové propojení } \\
\text { literární výchovy s hudební } \\
\text { výchovou. }\end{array}$ & $\begin{array}{l}\text { Vytleskej, jak déšt' } \\
\text { bubnuje na parapet. }\end{array}$ \\
\hline & $\begin{array}{l}\text { Umělecký } \\
\text { text - výtvarná } \\
\text { výchova }\end{array}$ & KS5 & $\begin{array}{l}\text { Mezioborové propojení } \\
\text { literární výchovy } \\
\text { s výtvarnou výchovou. }\end{array}$ & Nakresli ilustraci k básni. \\
\hline & $\begin{array}{l}\text { Umělecký } \\
\text { text - tělesná } \\
\text { výchova }\end{array}$ & KS6 & $\begin{array}{l}\text { Mezioborové propojení } \\
\text { literární výchovy s tělesnou } \\
\text { výchovou. }\end{array}$ & $\begin{array}{l}\text { Zacvič si rozcvičku podle } \\
\text { príběhu. }\end{array}$ \\
\hline
\end{tabular}




\begin{tabular}{|c|c|c|c|c|}
\hline Kategorie & Podkategorie & Kód & $\begin{array}{l}\text { Obsahové vymezení } \\
\text { podkategorie }\end{array}$ & Př́íklad \\
\hline \multirow{3}{*}{$\begin{array}{l}\text { Kontext } \\
\text { mimo- } \\
\text { estetický }\end{array}$} & Autor & KM1 & $\begin{array}{l}\text { Informace o životě } \\
\text { spisovatele. }\end{array}$ & $\begin{array}{l}\text { Proč se spisovatel zajímal } \\
\text { o psy? }\end{array}$ \\
\hline & $\begin{array}{l}\text { Další tvorba } \\
\text { autora }\end{array}$ & KM2 & $\begin{array}{l}\text { Informace o další tvorbě } \\
\text { spisovatele. }\end{array}$ & $\begin{array}{l}\text { Znáš nějakou další } \\
\text { písničku Zdeňka Svěráka? }\end{array}$ \\
\hline & $\begin{array}{l}\text { Literární } \\
\text { terminologie }\end{array}$ & KM3 & $\begin{array}{l}\text { Dobové reálie související } \\
\text { se vznikem či obsahem } \\
\text { textu, literární terminologie, } \\
\text { která však nemá souvislost } \\
\text { s textem. }\end{array}$ & Kdo je to romantik? \\
\hline \multirow{8}{*}{$\begin{array}{l}\text { Mimo- } \\
\text { textovost }\end{array}$} & Český jazyk & M1 & Reálie z českého jazyka. & Co je to synonymum? \\
\hline & Matematika & M2 & Reálie z matematiky. & Spočítej děti ve své třídě. \\
\hline & Náš svět & M3 & $\begin{array}{l}\text { Reálie z prvouky/ } \\
\text { př́rodovědy/ } \\
\text { vlastivědy. }\end{array}$ & Dovedou kuřátka mluvit? \\
\hline & $\begin{array}{l}\text { Hudební } \\
\text { výchova }\end{array}$ & M4 & Reálie z hudební výchovy. & $\begin{array}{l}\text { Zazpívej si nějakou } \\
\text { vánoční koledu. }\end{array}$ \\
\hline & $\begin{array}{l}\text { Výtvarná } \\
\text { výchova }\end{array}$ & M5 & Reálie z výtvarné výchovy. & $\begin{array}{l}\text { Jaké barvy může mít } \\
\text { petrklíč? }\end{array}$ \\
\hline & $\begin{array}{l}\text { Tělesná } \\
\text { výchova }\end{array}$ & M6 & Reálie z tělesné výchovy. & $\begin{array}{l}\text { Pohybuj se jako další } \\
\text { zvírata. }\end{array}$ \\
\hline & $\begin{array}{l}\text { Reálie ze } \\
\text { života žáka }\end{array}$ & M7 & Reálie z běžného života. & Už jsi byl někdy v galerii? \\
\hline & Ambivalentní & M8 & $\begin{array}{l}\text { Nejednoznačně určitelné } \\
\text { otázky, úkoly a náměty } \\
\text { k činnostem. }\end{array}$ & $\begin{array}{l}\text { Napiš a namaluj, kdo si } \\
\text { povídá. } \\
\text { Společně si prohlédněte } \\
\text { knihu Dášeňka. }\end{array}$ \\
\hline
\end{tabular}

Pro kvalitativní rozlišení jednotlivých kategorií ve smyslu jejich přímé vazby na umělecký text bylo nutné jejich vzájemné vymezení podle jejich směřování k prŕmé práci žáků s uměleckým textem. Stupeň kvality jednotlivých kategorií byl posuzován podle jejich obsahového směřování k naplnění přímé práce žáků s uměleckým textem. Každá kategorie kategoriálního systému představuje jeden ze čtyř stupňů kvality vymezených na stupnici 0-3. Kategorie Umělecký text (hodnocena stupněm 3) tak zcela naplňuje směřování didaktického aparátu k přímé práci žáků s uměleckým textem. Kategorie Kontext se sekundární estetickou funkcí (stupeň 2) a Kontext mimoestetický (stupeň 1) částečně naplňují přímou práci žáků s uměleckým textem. Kategorie Mimotextovost (stupeň 0) nenaplňuje práci žáků s uměleckým textem, což dokládáme v tabulce 2. 
Tabulka 2

Vymezení stupňu kvality v naplnění př́mé práce žáků s uměleckým textem v rámci jednotlivých kategorií

\begin{tabular}{|c|c|c|}
\hline Název kategorie & Stupeň kvality & Obsahové vymezení kategorie \\
\hline Umělecký text & 3 & $\begin{array}{l}\text { Vymezení struktury literárního díla na základě } \\
\text { identifikace jednotlivých složek nacházejících se } \\
\text { v naplnění struktury ideově-tematického základu, } \\
\text { věcného obsahu, autorského přístupu, kompozice } \\
\text { a jazykových prostředků. }\end{array}$ \\
\hline $\begin{array}{l}\text { Kontext se } \\
\text { sekundární } \\
\text { estetickou funkcí }\end{array}$ & 2 & $\begin{array}{l}\text { Naplnění vlastních kategorií uměleckého textu v těsném } \\
\text { sepětí s mimooborovým kontextem, který slouží } \\
\text { i ilustraci neliterárních vyučovacích předmětů (českého } \\
\text { jazyka, matematiky, prvouky, přírodovědy, vlastivědy, } \\
\text { výtvarné výchovy, hudební výchovy, tělesné výchovy). }\end{array}$ \\
\hline $\begin{array}{l}\text { Kontext } \\
\text { mimoestetický }\end{array}$ & 1 & $\begin{array}{l}\text { Vázanost námětů na literární historii a terminologii, } \\
\text { avšak bez př́mé souvislosti s uměleckým textem. }\end{array}$ \\
\hline Mimotextovost & 0 & $\begin{array}{l}\text { Vztah k mimotextové realitě, odklon od uměleckého } \\
\text { textu, směřování tematiky k reáliím neliterárních } \\
\text { vyučovacích předmětů (český jazyk, matematika, } \\
\text { prvouka, přírodověda, vlastivěda, výtvarná výchova, } \\
\text { hudební výchova, tělesná výchova). }\end{array}$ \\
\hline
\end{tabular}

\section{$4 \quad$ Výsledky výzkumu}

V následujících podkapitolách shrnujeme zjištěné výsledky výzkumu pro čítankovou řadu z nakladatelství Fraus a čítankovou řadu z nakladatelství SPN, které mezi sebou srovnáváme.

\subsection{Výsledky pro čítankovou řadu z nakladatelství Fraus}

Charakteristika celkových výsledků získaných pro čítankovou řadu nakladatelství Fraus prokazuje vysoké zastoupení kategorií Umělecký text (66 \%, dále jen Text) a Kontext se sekundární estetickou funkcí (18\%), reprezentujících směřování didaktického aparátu čítanek k přímé práci $\mathrm{s}$ uměleckým textem, a tedy i k naplnění estetickovýchovného pojetí literárního vzdělávání v primární škole. Nižší zastoupení kategorií Kontext mimoestetický (3\%) a Mimotextovost (13\%), které nekorespondují se směřováním didaktického aparátu čítanek k přímé práci žáků s uměleckým textem, rovněž potvrzuje tendence didaktického aparátu čítanek nakladatelství Fraus k naplnění práce žáků s uměleckým textem. 
Je však nutné dodat, že výsledky chí-kvadrát testu uvedené v tabulce 3 potvrdily značně nerovnoměrnou distribuci jednotlivých podkategorií v didaktickém aparátu čítanek z nakladatelství Fraus, a to zejména v kategoriích Text $\left(\chi^{2}=62,53 ; p<0,001\right)$ a Mimotextovost $\left(\chi^{2}=62,21 ; p<0,001\right)$, jejichž zastoupení $\mathrm{v}$ rámci směřování didaktického aparátu čítanek vedoucího k naplnění estetickovýchovného pojetí literárního vzdělávání v primární škole vymezujeme na opačných pólech kvality. Zjištěný výrazný nepoměr v zastoupení těchto kategorií (i podkategorií v jejich rámci) tak svědčí o nekonzistentním pojetí čítankové řady z nakladatelství Fraus.

Tabulka 3

Rozdíl výskytu kategorií v jednotlivých čítankách čítankové rady Fraus

\begin{tabular}{ccccc}
\hline & T & KS & KM & M \\
\cline { 2 - 5 } $2 . r$ & 228 & 151 & 23 & 163 \\
$3 . r$ & 408 & 107 & 15 & 55 \\
$4 . r$ & 437 & 78 & 20 & 74 \\
$5 . r$ & 562 & 102 & 29 & 44 \\
\cline { 2 - 5 }$\chi^{2}$ & 62,53 & 55,68 & 13,68 & 62,21 \\
\hline
\end{tabular}

Pozn. Pro zachování přehlednosti tabulky jsou v ní příslušné kategorie uvedeny následujícími kódy: $\mathrm{T}=$ Umělecký text, $\mathrm{KS}=$ Kontext se sekundární estetickou funkcí, $\mathrm{KM}=$ Kontext mimoestetický, $\mathrm{M}=$ Mimotextovost.

Na výrazné rozdíly $\mathrm{v}$ zastoupení jednotlivých kategorií poukázaly významné hladiny z-skóre v kategoriích Text ${ }^{12}$ a Mimotextovost ${ }^{13} \mathrm{u}$ čítanek určených pro 2., 4. a 5. ročník primární školy, přičemž pro směřování didaktického aparátu čítanek k estetickovýchovně pojaté literární výchově klíčová kategorie Text

12 Pro podkategorii T6 Smysl jsme zjistili statisticky významně vyšší zastoupení otázek/ úkolů/námětů k činnostem u čítanky pro 5. ročník $(\mathrm{z}=2,78)$ a nižší u čítanky pro 2. ročník $(\mathrm{z}=-4,01)$. Podkategorie T5 Téma je významně více zastoupena v čítankách pro 4. ročník $(\mathrm{z}=4,25)$ a 5 . ročník $(\mathrm{z}=2,11)$, méně u čítanky pro 2 . ročník $(\mathrm{z}=-4,55)$. Pro Podkategorii T2 Žánr jsme zjistili významně vyšší zastoupení u čítanky pro 5. ročník $(\mathrm{z}=3,78)$ a nižší u čítanek pro 2. ročník $(\mathrm{z}=-2,75)$ a 4 . ročník $(\mathrm{z}=-2)$. Podkategorie T1 Jazyk a styl je statisticky významně více zastoupena u čítanky pro 3 . ročník $(\mathrm{z}=2,48)$ a méně u čítanky pro 4. ročník $(\mathrm{z}=-2,22)$.

13 Podkategorie M3 Náš svět je oproti očekávání významně více zastoupena v čítankách pro 2. ročník $(\mathrm{z}=3,56)$ a méně u čítanek pro 4. ročník $(\mathrm{z}=-3,42)$ a 5 . ročník $(\mathrm{z}=-3,43)$. U podkategorie $M 7$ Reálie ze života jsme zjistili výrazně vyšší zastoupení u čítanky pro 2 ročník $(\mathrm{z}=3,85)$ a menší u čítanky pro 5. ročník $(\mathrm{z}=-2,03)$. Podkategorie $M 1$ Český jazyk je významně více zastoupena $v$ čítankách pro 3. ročník $(\mathrm{z}=2,93)$ a méně u čítanky pro 5 . ročník $(\mathrm{z}=2,84)$. U podkategorie M4 Hudební výchova jsme zjistili významně vyšší zastoupení v čítance pro 2 . ročník $(\mathrm{z}=3,85)$. 
$(13,6 \%)$ je v čítance pro 2 . ročník v rámci této kategorie zastoupena nejméně a zcela neliterární kategorie Mimotextovost (48,5\%) nejvíce. Didaktický aparát čítanky pro 2. ročník tedy nekoresponduje s estetickovýchovným pojetím literárního vzdělávání. Naopak didaktický aparát čítanek pro 3., 4. a 5. ročník dominantně naplňuje ve svém obsahu přímou práci s textem, což dokládáme na obrázku 2.

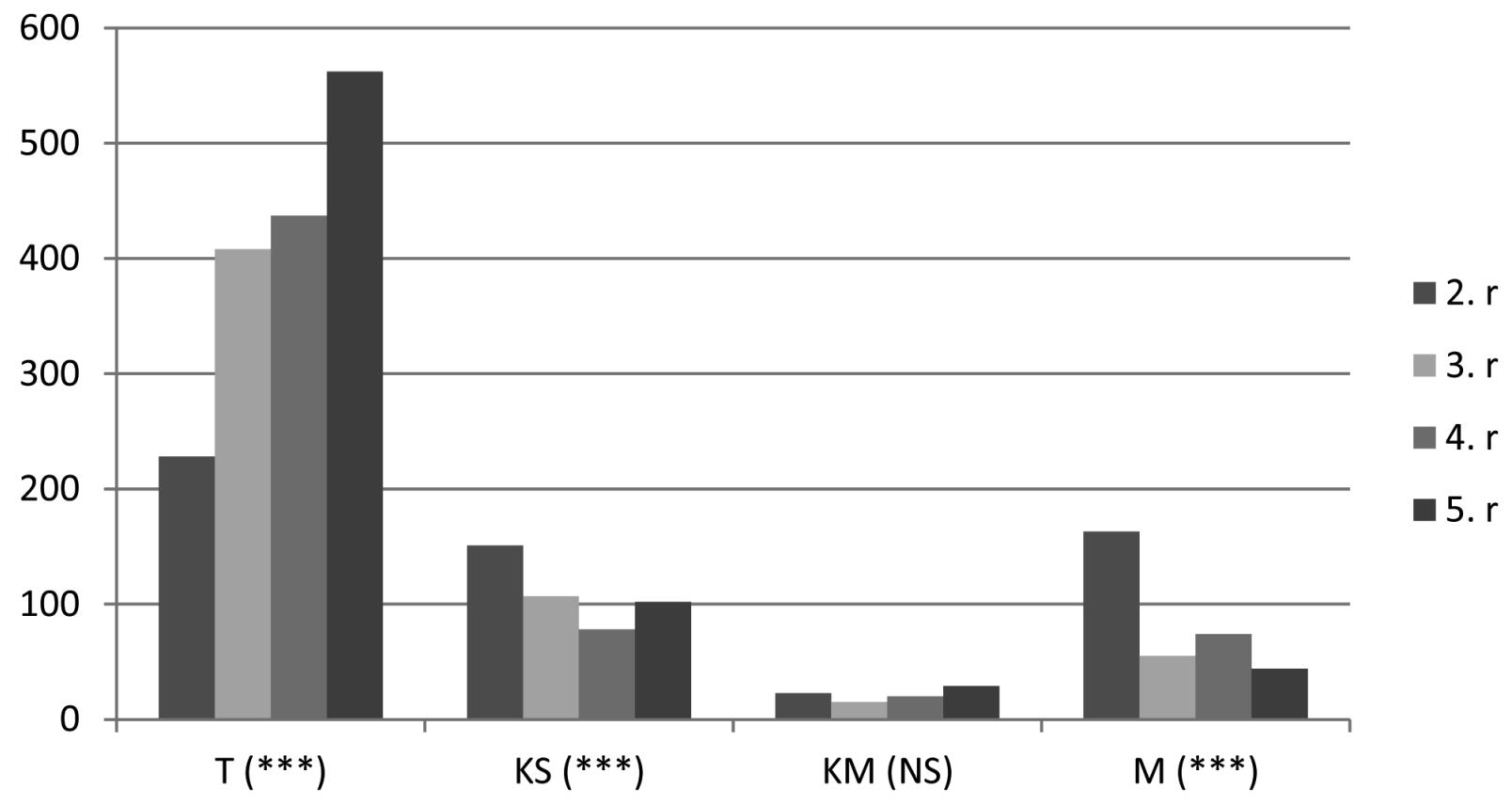

Obrázek 2. Poměr výskytu kategorií v jednotlivých čítankách čítankové řady Fraus.

Pozn. Zjištěná hodnota absolutní četnosti všech kategorií v čítankách nakladatelství Fraus byla 2496. Pro zachování přehlednosti grafu jsou v něm příslušné kategorie uvedeny následujícími kódy: $\mathrm{T}=$ Umělecký text, $\mathrm{KS}=$ Kontext se sekundární estetickou funkcí, $\mathrm{KM}=$ Kontext mimoestetický, $\mathrm{M}=$ Mimotextovost. Symbol $\left({ }^{* * *}\right)$ zastupuje hladinu významnosti $\mathrm{p}<0,001$. Značka (NS) non significant vyjadřuje, že zjištěný rozdíl absolutních četností není významný.

I přes vysoké hodnoty zastoupení kategorie Text však musíme konstatovat, že naplnění kategorie Text je v rámci jednotlivých podkategorií u všech analyzovaných čítanek značně nerozmanité, jelikož zde výrazně převažují otázky/úkoly a náměty k činnostem týkající se podkategorií Téma $(31,2 \%)$ a Smysl (30,8\%) a výrazně absentují kategorie Žánr (2,4\%), Intertextovost $(2,0 \%)$ a Vypravěč $(1,0 \%)$. Další zjištěné hodnoty uvádíme v tabulce 4 a na obrázku 3. 
Tabulka 4

Rozdíly výskytu podkategorií v kategorii Umělecký text vjednotlivých čítankách čítankové rady Fraus

\begin{tabular}{cccccc}
\hline & $2 . r$ & $3 . r$ & $4 . r$ & $5 . r$ & $\chi^{2}$ \\
\cline { 2 - 6 } T1 & 48 & 58 & 23 & 36 & 47,67 \\
T2 & 1 & 10 & 3 & 25 & 50,98 \\
T3 & 1 & 5 & 8 & 3 & 22,01 \\
T4 & 28 & 30 & 54 & 52 & 25,96 \\
T5 & 65 & 140 & 196 & 112 & 60,93 \\
T6 & 82 & 154 & 151 & 117 & 61,65 \\
T7 & 3 & 11 & 2 & 17 & 33,25 \\
\hline
\end{tabular}

Pozn. Pro zachování přehlednosti tabulky jsou v ní příslušné kategorie uvedeny následujícími kódy: $\mathrm{T} 1$ = Jazyk a styl, $\mathrm{T} 2=$ Žánr, T3 = Vypravěč, $\mathrm{T} 4=$ Kompozice, $\mathrm{T} 5=$ Téma, $\mathrm{T} 6=$ Smysl, T7 = Intertextovost.

Výrazné zastoupení otázek/úkolů a námětů k činnostem reflektujících tematiku uměleckého textu potvrzuje analogické výsledky výzkumů čítanek Hníka (2010) a Hoppeové (2011) a prokazuje, že didaktický aparát čítanek nepojímá umělecký text $\mathrm{v}$ jeho celistvosti, vzájemných vazbách a neoddělitelných souvislostech (srov. Lesňák, 1982), ale zaměřuje se zejména na snadno parafrázovatelnou tematickou oblast uměleckého textu. Naopak významně otázky/úkoly a náměty k činnostem podporující hledání smyslu čteného (prostřednictvím zážitku ze čtení a spontánní dětské tvořivosti) potvrzují směřování didaktického aparátu čítanek k smysluplné školní literární výchově (srov. Gejgušová, 2011, s. 13).

Za výrazný deficit této čítankové řady považujeme nízké, popřípadě žádné zastoupení podkategorií týkajících se výtvarné a hudební výchovy (absentuje v čítankách pro 4. a 5. ročník), a to nejen v rámci kategorie Kontext se sekundární estetickou funkcí, ale i v rámci kategorie Mimotextovost. Velmi nízké zastoupení těchto podkategorií bylo překvapující, jelikož se jedná o vyučovací předměty estetickovýchovného charakteru stavějící na předpokladu estetického zážitku (srov. Slavík, 2011). Uvážíme-li navíc, že jsou umělecké texty zařazené do čítanek z nakladatelství Fraus doprovázeny původními ilustracemi, což považujeme za velmi hodnotné, očekávali bychom větší sepětí didaktického aparátu čítanek s ilustracemi, čímž bychom vytvořili předpoklad k těsnějšímu provázání umělecky koncipovaných vzdělávacích oborů. 


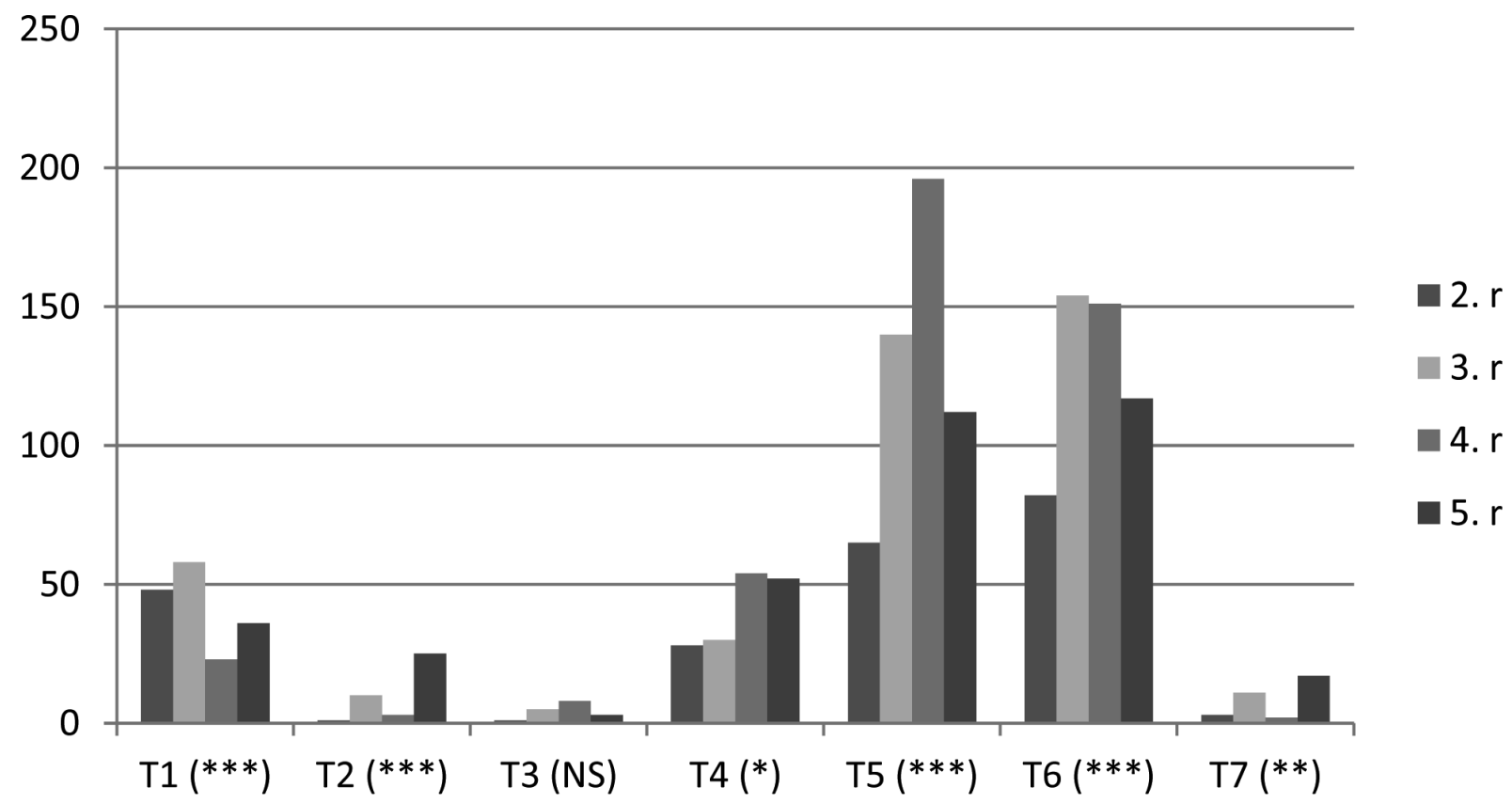

Obrázek 3. Komparace zastoupení podkategorií z kategorie Umělecký text v jednotlivých čítankách čítankové řady Fraus.

Pozn. Zjištěná hodnota absolutní četnosti všech podkategorií kategorie Umělecký text v celém výzkumném souboru byla 1635. Pro zachování přehlednosti grafu jsou v něm příslušné kategorie uvedeny následujícími kódy: Pro zachování přehlednosti grafu jsou v něm př́íslušné podkategorie uvedeny následujícími kódy: T1 = Jazyk a styl, T2 = Žánr, T3 = Vypravěč, T4 = Kompozice, T5 = Téma, T6 = Smysl, T7 = Intertextovost. Symboly užité v grafu $(* * * / * * * *)$ udávají 3 hladiny významnosti $p$. Symbol $\left(^{* * *}\right.$ ) zastupuje hladinu významnosti $p<0,001$; symbol $\left.{ }^{* *}\right)$ reprezentuje hladinu významnosti $\mathrm{p}<0,01$ a symbol $\left(^{*}\right)$ označuje hladinu významnosti $\mathrm{p}<0,05$. Značka (NS) non significant vyjadřuje, že zjištěný rozdíl absolutních četností není významný.

\subsection{Výsledky pro čítankovou řadu z nakladatelství SPN}

Při srovnání výsledků analýzy čítankové řady z nakladatelství SPN bylo překvapivým zjištěním, že celkové zastoupení kategorie Text (40 \%), reprezentující směřování didaktického aparátu čítanek k naplnění př́ímé práce $\mathrm{s}$ uměleckým textem, a tedy k naplnění obsahu estetickovýchovného pojetí literárního vzdělávání, a celkové zastoupení kategorie Mimotextovost (34\%), směřující didaktický aparát čítanek k ilustraci různých obsahů neliterárních školních předmětů, je v čítankách nakladatelství SPN poměrně vyrovnané. Vysoké zastoupení kategorie Mimotextovost, které je charakteristické pro celou čítankovou řadu nakladatelství SPN, zvláště pak pro čítanku pro 2. ročník, považujeme za nejvýraznější deficit těchto čítanek. Zastoupení 
kategorie Kontext se sekundární estetickou funkcí propojující zaměření didaktického aparátu čítanek na umělecký text s obsahy neliterárních školních předmětů pak téměř dosahuje očekávané průměrné hodnoty $(20 \%)$. Literárněteoretická kategorie nevztahující se $\mathrm{k}$ př́mé práci žáků $\mathrm{s}$ uměleckým textem Kontext mimoestetický není v didaktickém aparátu zkoumaného souboru čítanek z nakladatelství SPN výrazně zastoupena (4 \%). Zjištěné hodnoty zastoupení jednotlivých kategorií v rámci jednotlivých ročníkủ čítanek z nakladatelství SPN dokladujeme v tabulce 5 a na obrázku 4.

Tabulka 5

Rozdíly výskytu kategorií v jednotlivých čítankách čítankové řady SPN

\begin{tabular}{ccccc}
\hline & T & KS & KM & M \\
\cline { 2 - 5 } $2 . r$ & 47 & 46 & 11 & 120 \\
3. $r$ & 78 & 38 & 7 & 72 \\
4. & 145 & 59 & 24 & 66 \\
$5 . r$ & 96 & 49 & 14 & 62 \\
$\chi^{2}$ & 37,71 & 8,40 & 19,42 & 56,93 \\
\hline
\end{tabular}

Pozn. Pro zachování přehlednosti tabulky jsou v ní příslušné kategorie uvedeny následujícími kódy: $\mathrm{T}=$ Umělecký text, $\mathrm{KS}=$ Kontext se sekundární estetickou funkcí, $\mathrm{KM}=$ Kontext mimoestetický, $\mathrm{M}=$ Mimotextovost.

Zjistili jsme, že vysoké zastoupení kategorie Text (40 \%) je způsobeno dominantním výskytem této kategorie u čítanky pro 4. ročník $(39,6 \%)$ ve srovnání s ostatními čítankami, přičemž nejvýrazněji se v rámci kategorie Text vyskytují podkategorie Téma (14,6\%) a Smysl (14,2 \%), a to u všech zkoumaných čítanek nakladatelství SPN, nejvýrazněji pak opět u čítanky pro 4. ročník (Téma 36,7 \%; Smysl 32,4%). Za výrazný deficit čítanek nakladatelství SPN týkající se kategorie Text považujeme absenci či velmi nízké zastoupení (absolutní četnost 1) podkategorií Vypravěč a Intertextovost. Toto zjištění interpretujeme $\mathrm{v}$ analogii s výše prezentovanými výsledky čítankové řady Fraus a předchozími výzkumy čítanek (Hník, 2010; Hoppeová, 2011) jako nerespektování celistvé, navzájem propojené umělecké textové roviny v didaktickém aparátu čítanek. Jsme si však vědomi, že se zvláště v nejnižších ročnících primární školy vzhledem $\mathrm{k}$ dosažené čtenářské vyspělosti žákủ některé roviny textů (např. žánr) marginalizují. Ve shodě s výsledky analýzy čítanek Hníka (2010) jsme rovněž zaznamenali výrazně vyšší výskyt v zastoupení u podkategorie Jazyk a styl, jejíž dominanci reflektujeme u čítanky pro 3. ročník $(12,0 \%)$. Zjištění si lze vysvětlit snahou autorů čítanky reflektovat 
požadavky RVP ZV v jejím didaktickém aparátu, jelikož ve 3. ročníku se uzavírají očekávané výstupy pro 1 . období primární školy (viz RVP ZV, 2007, s. 6). Zdokonalování žáků v užívání mateřského jazyka je jednou z klíčových oblastí očekávaných výstupů 1. období. Osvojování poeticky zaměřených jazykových kategorií vycházející z př́mého kontaktu žáka s uměleckým textem hodnotíme $\mathrm{z}$ hlediska estetickovýchovného pojetí literárního vzdělávání jako přínosné.

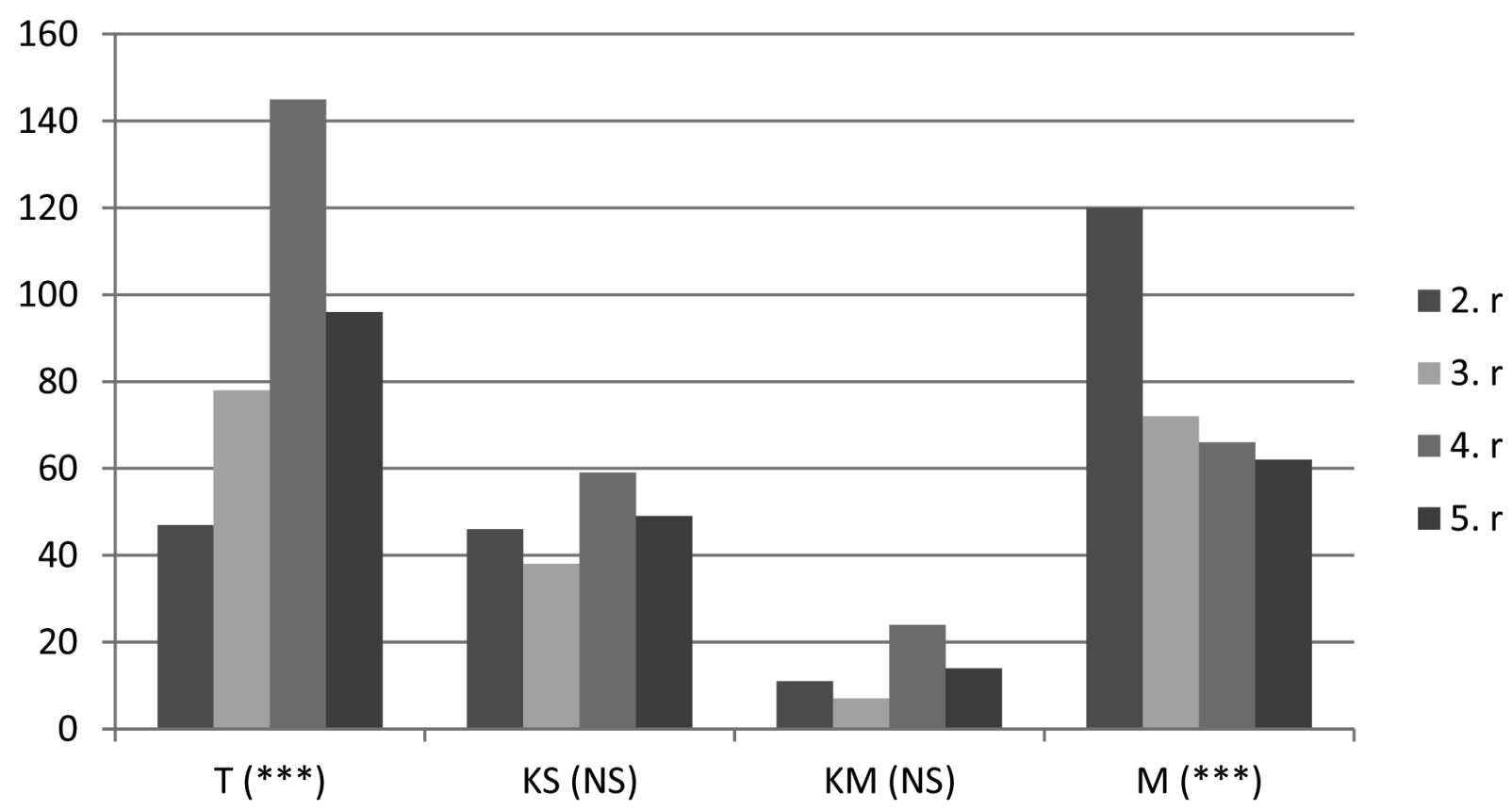

Obrázek 4. Komparace zastoupení kategoriív jednotlivých čítankách čítankové řady SPN.

Pozn. Zjištěná hodnota absolutních četností všech kategorií v čítankách z nakladatelství SPN byla 954. Pro zachování přehlednosti grafu jsou v něm příslušné kategorie uvedeny následujícími kódy: $\mathrm{T}=$ Umělecký text, $\mathrm{KS}=$ Kontext se sekundární estetickou funkcí, $\mathrm{KM}=$ Kontext mimoestetický, $\mathrm{M}=$ Mimotextovost. Symboly užité v grafu (***/** $/ *)$ udávají 3 hladiny významnosti $\mathrm{p}$. Symbol $(* * *)$ zastupuje hladinu významnosti $\mathrm{p}<0,001$; symbol $(* *)$ reprezentuje hladinu významnosti $\mathrm{p}<0,01$ a symbol $\left({ }^{*}\right)$ označuje hladinu významnosti $\mathrm{p}<0,05$. Značka (NS) non significant vyjadřuje, že zjištěný rozdíl absolutních četností není významný.

Výše uvedené poměry v zastoupení kategorií Text a Mimotextovost v jednotlivých ročnících čítanek pak můžeme interpretovat tak, že čítanka pro 2. ročník, v jejímž didaktickém aparátu oproti očekávání výrazně dominuje zastoupení kategorie Mimotextovost a významně absentuje zastoupení kategorie Text, paradoxně nesměřuje $\mathrm{k}$ naplnění komunikačně pojaté školní 
literární výchovy ve svém didaktickém aparátu, jelikož jak uvádí Liptáková (2011, s. 28), „primární vzdělávání je fundamentální a formující právě ve výchově slovesným uměním“. Naopak čítanka pro 4. ročník s nízkým zastoupením hodnot v kategorii Mimotextovost a nejvyššími zjištěnými četnostmi v kategorii Text upřednostňuje ve svém didaktickém aparátu otázky/úkoly/ náměty $\mathrm{k}$ činnostem odpovídající požadavkům estetickovýchovně pojaté literární výchovy v primární škole.

Vysokou hodnotu celkového zastoupení a rovnoměrnou distribuci v rámci všech čítanek nakladatelství SPN jsme zjistili v kategorii Kontext se sekundární estetickou funkcí u podkategorie Literární výchova - výtvarná výchova $(2,4 \%)$ a podkategorie Výtvarná výchova $(3,5 \%)$, což si lze vysvětlit jako snahu autorů čítanek SPN o mezioborovou propojenost těchto estetickovýchovných předmětů.

\subsection{Komparace výsledkủ čítankových řad z nakladatelství Fraus a SPN}

Obě zkoumané čítankové řady vykazují shodné rysy v hodnotách celkového zastoupení jednotlivých kategorií. Významné rozdíly ve zkoumaných čítankových řadách reflektujeme $\mathrm{v}$ míře a rozmanitosti zastoupení jednotlivých podkategorií.

\section{Kategorie Text}

Při komparaci čítankových řad v kategorii Text jsme sice zjistili celkové vysoké zastoupení této kategorie v obou čítankových řadách (Fraus $66 \%$; SPN $40 \%$ ), chí-kvadrát test však prokázal, že počet otázek/úkolů/námětů k činnostem spadajících do této kategorie je výrazně vyšší v čítankách z čítankové řady nakladatelství Fraus než v čítankové řadě z nakladatelství SPN, což ilustrujeme v tabulce 6 a na obrázku 5 .

Tabulka 6

Rozdíly výskytu podkategorií kategorie Umělecký text mezi čítankami z nakladatelství Fraus a SPN

\begin{tabular}{ccccccccc}
\hline & T1 & T2 & T3 & T4 & T5 & T6 & T7 & $\sum$ \\
\cline { 2 - 9 } Fraus & 165 & 39 & 17 & 164 & 613 & 604 & 33 & 1635 \\
SPN & 61 & 16 & 2 & 26 & 139 & 136 & 6 & 386 \\
\cline { 2 - 9 }$\chi^{2}$ & 0,05 & 0,06 & 2,80 & 19,61 & 29,19 & 26,18 & 2,98 & 31,06 \\
\hline
\end{tabular}

Pozn. Pro zachování přehlednosti tabulky jsou v ní příslušné podkategorie uvedeny následujícími kódy:T1 = Jazyk a styl, T2 = Žánr, T3 = Vypravěč, T4 = Kompozice, T5 = Téma, T6 = Smysl, $\mathrm{T} 7$ = Intertextovost. 


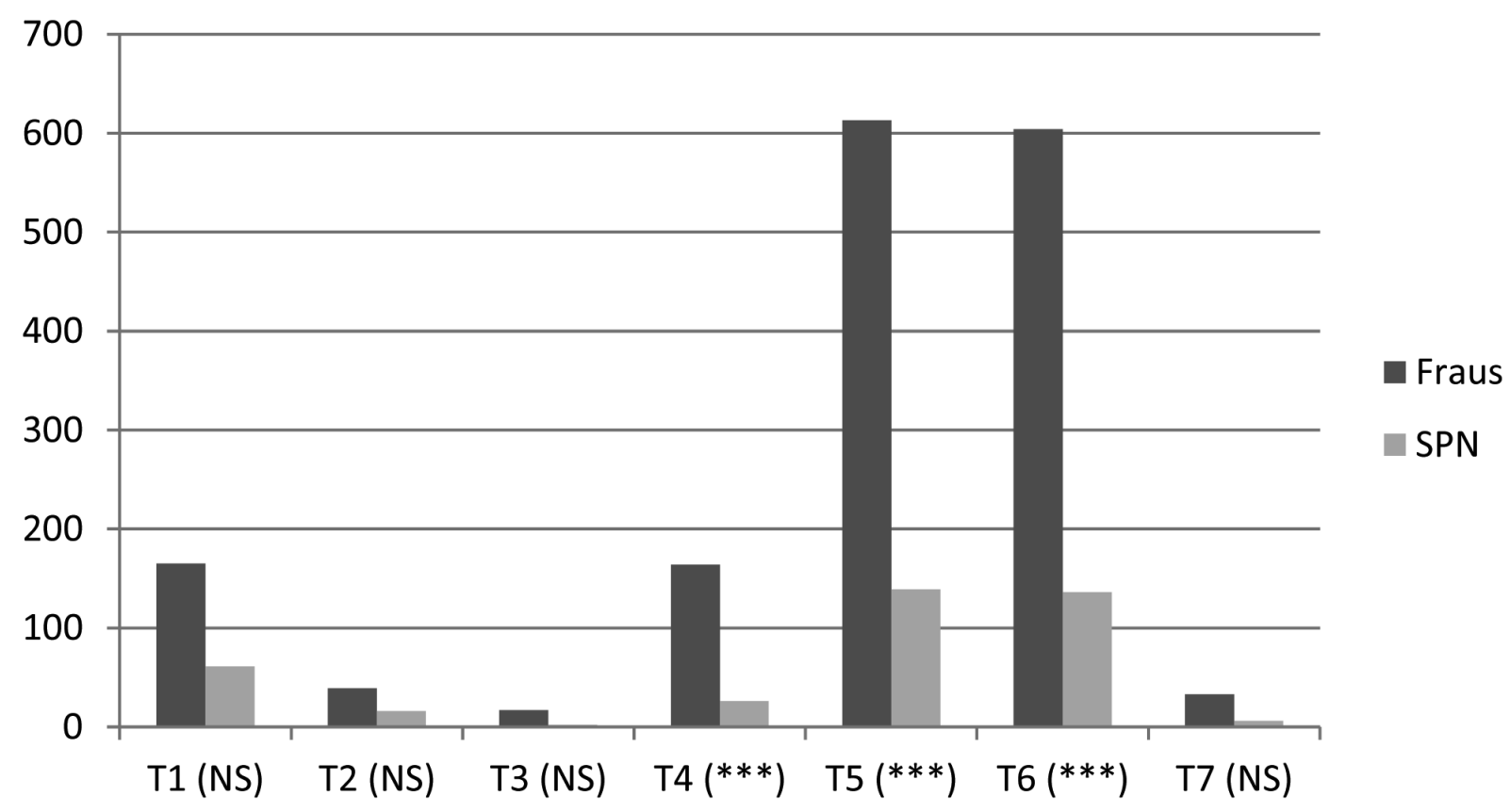

Obrázek 5. Komparace zastoupení podkategorií z kategorie Umělecký text mezi čítankami z nakladatelství Fraus a SPN.

Pozn. Zjištěná hodnota absolutní četnosti všech podkategorií kategorie Umělecký text byla pro celý výzkumný soubor 2021. Pro zachování přehlednosti grafu jsou v něm příslušné podkategorie uvedeny následujícími kódy: T1 = Jazyk a styl, T2 = Žánr, T3 = Vypravěč, T4 = Kompozice, T5 = Téma, T6 = Smysl, T7 = Intertextovost. Symbol $\left({ }^{* * *}\right)$ zastupuje hladinu významnosti $\mathrm{p}<0,001$. Značka (NS) non significant vyjadřuje, že zjištěný rozdíl absolutních četností není významný.

V čítankové řadě Fraus i v čítankové řadě SPN jsou v rámci kategorie Text zastoupeny výrazně vyššími četnostmi otázky/úkoly a náměty k činnostem týkající se podkategorií Téma (Fraus 37,5\%; SPN 36,0\%) a Smysl (Fraus $36,9 \%$; SPN 35,2 \%).

Dominantní zastoupení otázek/úkolů a námětů k činnostem vztahujícím se $\mathrm{k}$ oblastem tematiky a smyslu uměleckého textu značí ( $\mathrm{v}$ analogii s výsledky výzkumu čítanek Hníka [2010] a Hoppeové [2011]) ambivalentní reflektování uměleckého textu v didaktickém aparátu čítanek, jelikož tematicky (extenzionálně, věcně) zaměřený didaktický aparát vykazuje rysy pragmatického pojetí čtenářství (Campbell \& Mullis et al., 2001), naproti tomu interpretačně orientovaný didaktický aparát prokazuje orientaci k estetickovýchovně pojaté literární výchově. 
Ostatní podkategorie kategorie Text v čítankové řadě Fraus vykazují napříč jednotlivými ročníky značné rozdíly v míře zastoupení, což svědčí o nerovnoměrném zastoupení jednotlivých podkategorií, které lze interpretovat jako nereflektování celistvosti a vzájemné provázanosti složek uměleckého textu v didaktickém aparátu čítanek (srov. Peterka, 2009), a to zvláště v případech, kdy u obou čítankových řad shodně vykazují velmi nízké hodnoty zastoupení podkategorie Žánr (Fraus 2,4\%; SPN 4,2 \%), Intertextovost (Fraus 2,0 \%; SPN 1,6 \%) a Vypravěč (Fraus 1,0\%; SPN 0,5\%). $\mathrm{Na}$ druhou stranu je pochopitelné, že se zvláště v nejnižších ročnících primární školy vzhledem $\mathrm{k}$ dosažené čtenářské vyspělosti žákủ některé roviny textů (např. žánr) marginalizují (srov. RVP ZV, 2007, s. 22).

Co se týká srovnání rozdílů $\mathrm{v}$ zastoupení kategorie Text $\mathrm{v}$ jednotlivých čítankách nakladatelství Fraus a SPN, najdeme napříč ročníky zkoumaných čítankových řad značné množství shodných rysů:

- nejvýraznější hodnotu zastoupení kategorie Text reflektujeme shodně u čítanek pro 4. ročník, což svědčí o jejich nejvýraznějším směřování k naplnění komunikační koncepce literárního vzdělávání prostřednictvím jejich didaktického aparátu;

- nejnižší četnost zastoupení kategorie Text reflektujeme shodně u čítanek pro 2. ročník, což lze interpretovat jako neliterární směřování těchto čítanek;

- nejvyrovnanější hodnoty $\mathrm{v}$ četnosti i rozmanitosti zastoupení jednotlivých podkategorií kategorie Text vykazují čítanky pro 3. ročník obou nakladatelství, které můžeme v tomto ohledu považovat za nejvyváženější.

Při srovnání zastoupení př́mé práce $\mathrm{s}$ uměleckým textem $\mathrm{v}$ didaktickém aparátu analyzovaných čítankových řad jednoznačně dominuje čítanková řada nakladatelství Fraus, která je však ve srovnání s čítankovou řadou nakladatelství SPN díky výrazně nerovnoměrnému zastoupení jednotlivých podkategorií nekonzistentní. Ze srovnání jednotlivých ročníků čítanek jsme zjistili výrazné směřování $\mathrm{k}$ naplnění přímé práce $\mathrm{s}$ uměleckým textem tedy k naplnění estetickovýchovnéhopojetí literárního vzdělávání u didaktického aparátu čítanky pro 4. ročník nakladatelství Fraus. Za neliterární pak můžeme označit pojetí didaktického aparátu u čítanek pro 2. a 3. ročník nakladatelství SPN. 


\section{Kategorie Kontext se sekundární estetickou funkcí}

Při komparaci čítankových řad v kategorii Kontext se sekundární estetickou funkcí jsme zjistili, že počet otázek/úkolů/námětů k činnostem spadajících do této kategorie je výrazně vyšší v čítankách z čítankové řady nakladatelství Fraus $(69,5 \%)$ než v čítankové řadě z nakladatelství SPN (30,5 \%).

Shodným rysem čítanek z celého zkoumaného souboru je nízká míra rozmanitosti zastoupení jednotlivých podkategorií, kdy se v celém výzkumném souboru čítanek vyskytují nejvyšší hodnoty zastoupení u podkategorií Umělecký text - český jazyk (11,9\%) a Umělecký text - náš svět (4,3 \%), což dokládáme v tabulce 7 a na obrázku 6.

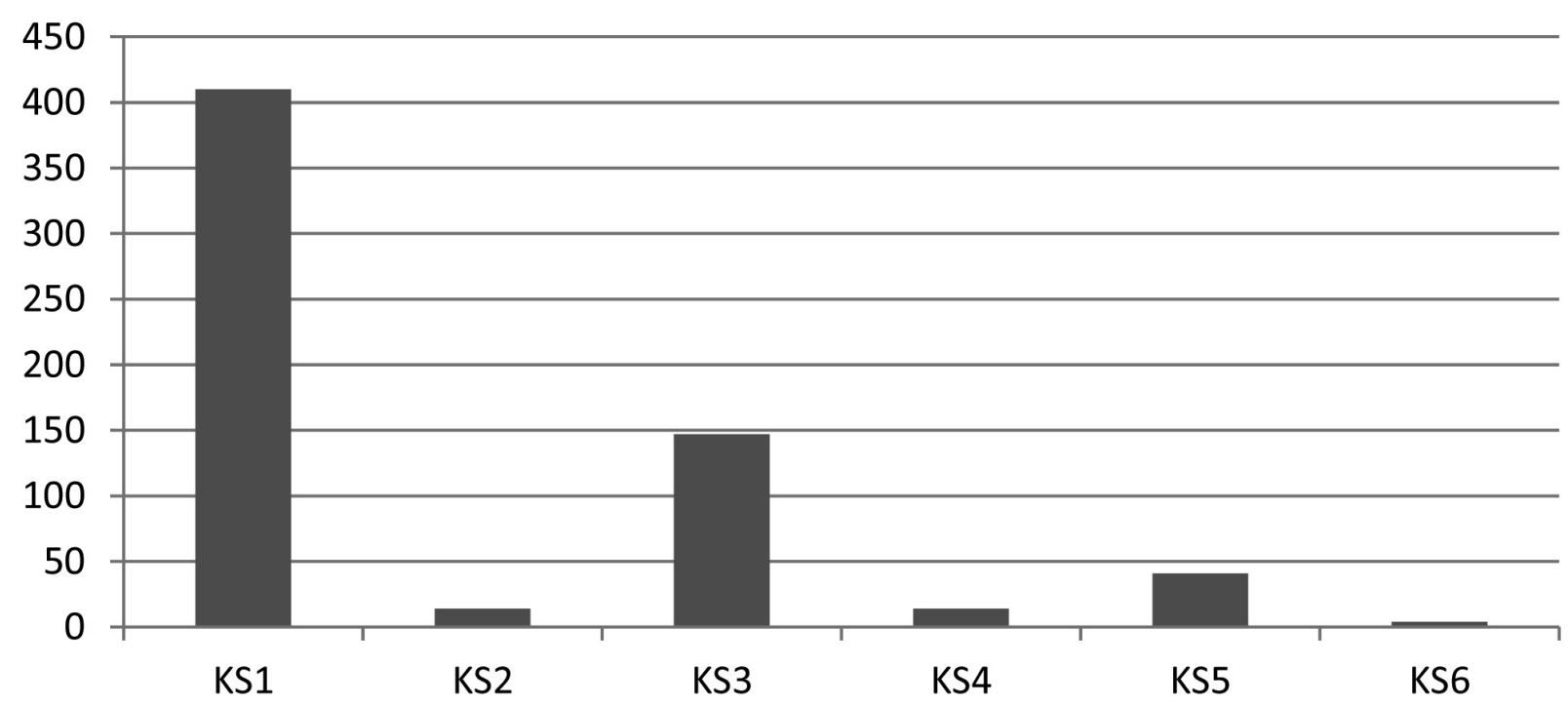

Obrázek 6. Celkové zastoupení jednotlivých podkategorií v kategorii Kontext se sekundární estetickou funkcí v celém výzkumném souboru.

Pozn. Zjištěná hodnota absolutní četnosti všech podkategorií kategorie Kontext se sekundární estetickou funkcí byla pro celý výzkumný soubor 630. Pro zachování přehlednosti grafu jsou v něm příslušné podkategorie uvedeny následujícími kódy: KS1= Umělecký text - český jazyk, KS2 = Umělecký text - matematika, KS3 = Umělecký text - náš svět, KS4 = Umělecký text - hudební výchova, KS5 = Umělecký text - výtvarná výchova, KS6 = Umělecký text - tělesná výchova. 
Tabulka 7

Absolutní četnosti jednotlivých podkategorií v kategorii Kontext se sekundární estetickou funkcí v celém výzkumném souboru.

\begin{tabular}{cccccccc}
\hline & KS1 & KS2 & KS3 & KS4 & KS5 & KS6 & $\sum$ \\
\cline { 2 - 8 } Fraus & 310 & 1 & 105 & 2 & 18 & 2 & 438 \\
SPN & 100 & 13 & 42 & 12 & 23 & 2 & 192 \\
\hline$\sum$ & 410 & 14 & 147 & 14 & 41 & 4 & 630 \\
\hline
\end{tabular}

Pozn. Počet analyzovaných jednotek všech podkategorií byl v celém výzkumném souboru roven hodnotě 3450. Pro zachování přehlednosti tabulky jsou v ní př́íslušné podkategorie uvedeny následujícími kódy: KS1= Umělecký text - český jazyk, KS2 = Umělecký text - matematika, KS3 = Umělecký text - náš svět, KS4 = Umělecký text - hudební výchova, KS5 = Umělecký text výtvarná výchova, KS6 = Umělecký text - tělesná výchova.

Vysoké zastoupení podkategorie Umělecký text - český jazyk si lze vysvětlit úzkou provázaností školní literární výchovy s výukou mateřského jazyka, jejíž prvky se vhodně promítají do didaktického aparátu čítanek, jelikož vycházejí z př́imé práce žáků s uměleckým textem. Vysoké četnosti zastoupení podkategorie Umělecký text - náš svět můžeme interpretovat s ohledem na mnohovrstevnatý tematický potenciál uměleckých textů (Peterka, 2009), jejichž různorodé tematické zaměření př́ímo vybízí, zvlášt' v primární škole, k propojení školních předmětů literární výchovy a našeho světa.

Co se týká významných rozdílů zjištěných v kategorii Kontext se sekundární estetickou funkcí, můžeme konstatovat, že statisticky významné hodnoty chí-kvadrátu prokázaly významně vyšší zastoupení podkategorií Umělecký text - hudební výchova $\left(\chi^{2}=23,69 ; \mathrm{p}<0,001\right)$ a Umělecký text - výtvarná výchova $\left(\chi^{2}=16,78 ; \mathrm{p}<0,001\right)$ v čítankách nakladatelství SPN než v čítankách nakladatelství Fraus. Celkové velmi nízké četnosti zastoupení těchto podkategorií (Umělecký text - hudební výchova: Fraus 0,1\%; SPN 0,4\%; Umělecký text - výtvarná výchova: Fraus 0,5 \%; SPN 0,7 \%) zároveň prokazují, že didaktický aparát v čítankách nakladatelství Fraus bohužel nezohledňuje možné propojení školních estetickovýchovných předmětů literární výchovy, hudební výchovy a výtvarné výchovy, ačkoliv velmi vhodně doplňuje čítankové texty původními ilustracemi, což považujeme za hodnotné (srov. Zítková, 2005). Naopak čítanky nakladatelství SPN, zvláště pak čítanka pro 4. ročník, prokazují vyrovnané zastoupení těchto podkategorií i celkovou konzistentnost zastoupení všech podkategorií z kategorie Kontext se sekundární estetickou funkcí. 


\section{Kategorie Kontext mimoestetický}

Kategorie Kontext mimoestetický je nejméně zastoupenou podkategorií v celém výzkumném souboru (4\%) i v jednotlivých čítankových řadách (Fraus $3 \%$; SPN $6 \%$ ), což si lze vysvětlit nejnižším počtem jejích podkategorií (celkem 3) ve srovnání s ostatními kategoriemi. Co se týče zjištěných rozdílů $\mathrm{v}$ rámci srovnání zkoumaných čítankových řad, zjistili jsme statisticky významné rozdíly v zastoupení u všech podkategorií, což dokládáme v tabulce 8 a na obrázku 7.

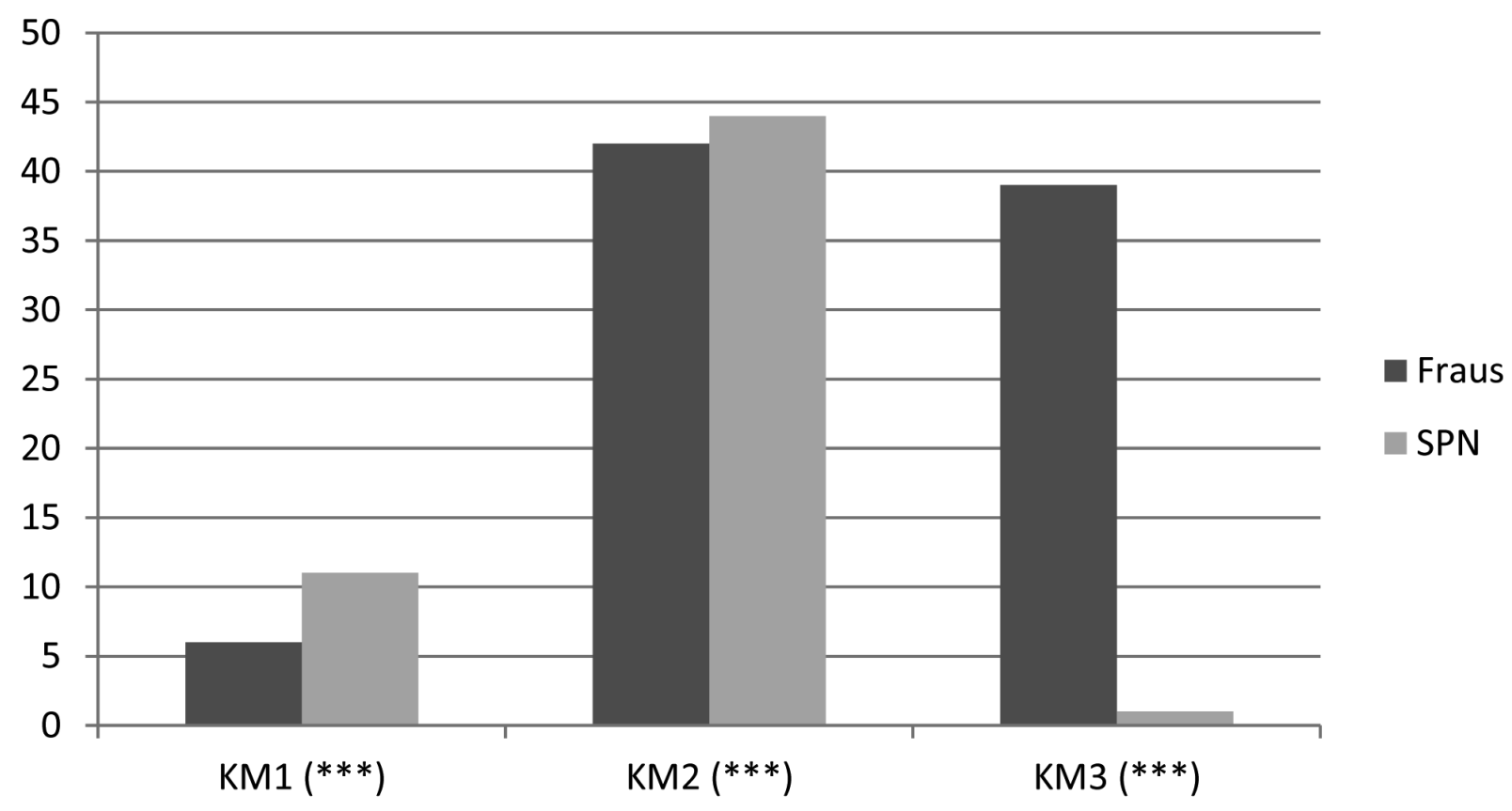

Obrázek 7. Komparace zastoupení podkategorií z kategorie Kontext mimoestetický mezi čítankami z nakladatelství Fraus a SPN.

Pozn. Zjištěná hodnota absolutní četnosti všech podkategorií kategorie Kontext mimoestetický byla pro celý výzkumný soubor 143. Pro zachování přehlednosti grafu jsou v něm př́slušné podkategorie uvedeny následujícími kódy:KM1 = Autor, KM2 = Další tvorba autora, KM3 = Literární terminologie. Symbol $\left({ }^{* * *}\right)$ zastupuje hladinu významnosti $\mathrm{p}<0,001$. 
Tabulka 8

Rozdíly výskytu podkategorií z kategorie Kontext mimoestetickýmezi čítankami z nakladatelství Fraus a SPN

\begin{tabular}{ccccc}
\hline & KM1 & KM2 & KM3 & $\Sigma$ \\
\cline { 2 - 5 } Fraus & 6 & 42 & 39 & 87 \\
SPN & 11 & 44 & 1 & 56 \\
\cline { 2 - 5 }$\chi^{2}$ & 11,72 & 24,37 & 21,87 & 9,59 \\
\hline
\end{tabular}

Pozn. Pro zachování přehlednosti tabulky jsou v ní příslušné podkategorie uvedeny následujícími kódy: KM1 = Autor, KM2 = Další tvorba autora, KM3 = Literární terminologie.

V didaktickém aparátu čítankové řady nakladatelství SPN se ve srovnání s čítankami nakladatelství Fraus významně více vyskytují otázky/úkoly a náměty k činnostem týkající se kategorie Další tvorba autora $\left(\chi^{2}=24,37 ; \mathrm{p}<0,001\right)$ a Autor $\left(\chi^{2}=11,72 ; p<0,001\right)$. Významné zastoupení těchto kategorií, které však nevycházejí z přímé práce s uměleckým textem, signalizuje směřování čítanek nakladatelství SPN k neliterárnímu pojetí, a to z důvodu nemožnosti konfrontace fikčního světa literárního díla (srov. Doležel, 2003) s biografickými či literárně-teoretickými kontexty, k nimž směřuje povaha zadání didaktického aparátu čítanek SPN, jež je v tomto faktografickém pojetí bez zřetele $k$ uměleckému textu odklání od komunikačně zaměřené literární výchovy (srov. Hník, 2010). S ohledem na nejčetnější zastoupení těchto podkategorií u čítanky nakladatelství SPN pro 5. ročník uznáváme potřebu budování literárněteoretických znalostí (srov. Janoušek, 2009, s. 11). Přesto bychom v estetickovýchovně pojaté literární výchově preferovali, aby tyto znalosti př́mo vycházely z konkrétní recepce textů umělecké literatury žáky a specifického komunikačního procesu odehrávajícího se ve školní literární výchově.

\section{Kategorie Mimotextovost}

Komparace čítankových řad nakladatelství Fraus a SPN v kategorii Mimotextovost prokázala významné rozdíly $\mathrm{v}$ zastoupení této kategorie $\mathrm{v}$ čítankách nakladatelství SPN v porovnání s čítankami nakladatelství Fraus, a to zejména v podkategoriích Výtvarná výchova $\left(\chi^{2}=28,25 ; \mathrm{p}<0,001\right)$ a Ambivaletní $\left(\chi^{2}=11,98 ; \mathrm{p}<0,001\right)$. Zjištěný nepoměr $\mathrm{v}$ hodnotách zastoupení neliterární kategorie Mimotextovost mezi čítankami nakladatelství Fraus a SPN potvrzuje analogická zjištění u kategorie Text a shodně tak pojímá čítanky 
nakladatelství Fraus jako čítanky, jejichž didaktický aparát zohledňuje estetickovýchovné pojetí literárního vzdělávání, a čítanky z nakladatelství SPN jako čítanky neliterárního charakteru.

Při srovnávání rozdílů v zastoupení kategorie Mimotextovost v jednotlivých čítankách nakladatelství Fraus a SPN nalezneme napříč jednotlivými ročníky zkoumaných čítankových řad značné množství shodných rysů:

- S odvoláním na výše prezentovaná zjištění u kategorie Kontext se sekundární estetickou funkcí bychom chtěli upozornit na analogické výsledky týkající se nerovnoměrného zastoupení jednotlivých podkategorií kategorie Mimotextovost, kde je rovněž nejvýrazněji zastoupena podkategorie Český jazyk (Fraus 4,1\%; SPN 10,4\%) a Náš svět (Fraus 4,4\%; SPN $8,5 \%$ ). Při srovnání jednotlivých ročníků čítanek se tato tendence objevuje v čítankách pro 2. ročník u obou nakladatelství (FrausM3 Prvouka $\left[\chi^{2}=63,89 ; \mathrm{p}<0,001 ; \mathrm{z}=3,56\right]$, SPNM3 Prvouka $\left[\chi^{2}=53,52 ; \mathrm{p}<0,001\right.$; $\mathrm{z}=3,58]$ ) ve srovnání s ostatními ročníky analyzovaných čítanek.

- Nejnižší zastoupení kategorie Mimotextovost jsme zjistili u čítanek pro 4. a 5. ročník obou nakladatelství (Fraus 4. ročník 3,0 \%; Fraus 5. ročník 1,8 \%; SPN 4. ročník 6,9\%; SPN 5. ročník 6,5 \%).

Z výše uvedených zjištění můžeme konstatovat, že analyzované čítanky pro 2. ročník ve svém didaktickém aparátu shodně vykazují nejvyšší příklon k ilustraci neliterárních školních předmětů, čímž se odklánějí od estetickovýchovně pojaté literární výchovy v primární škole. Čítanky pro 3. ročník jsou z hlediska literárního a neliterárního zaměření spíše neutrální. Nejvyšší příklon ke komunikačně pojatému literárnímu vzdělávání v primární škole prokázaly zjištěné hodnoty u čítanek pro 4 . a 5. ročník.

\subsection{Shrnutí podkapitoly}

Cílem této podkapitoly je shrnout výsledky našeho výzkumu a pokusit se tak o zodpovězení námi položených výzkumných otázek:

- Do jaké míry se didaktický aparát analyzovaných čítanek vztahuje $k$ umèleckému textu a jaké je zastoupení jednotlivých oblastí jeho struktury?

Analýza ukázala, že se k uměleckému textu vztahuje většina otázek, úkolů a námětů $\mathrm{k}$ činnostem zařazených do didaktického aparátu všech zkoumaných čítanek (59\%). Zároveň jsme zjistili, že zastoupení jednotlivých oblastí struktury uměleckého textu je v didaktickém aparátu analyzovaných čítanek nerovnoměrné. 
Míra zastoupení otázek/úkolů a námětů k činnostem vztahujících se k uměleckému textu jednoznačně dominuje u čítanek nakladatelství Fraus $\left(\chi^{2}=63,89\right.$; $\mathrm{p}<0,001) \mathrm{v}$ porovnání s čítankami nakladatelství SPN. Zastoupení jednotlivých podkategorií reprezentujících oblasti struktury uměleckého textu však vykazuje u jednotlivých ročníků čítanek nakladatelství Fraus významné rozdíly ${ }^{14}$. Nerovnoměrné zastoupení jednotlivých oblastí struktury uměleckého textu u všech čítanek nakladatelství Fraus vypovídá o nekonzistentním pojetí didaktického aparátu vztahujícímu se k vlastním rovinám uměleckému textu. Na základě provedené analýzy čítanek z nakladatelství Fraus můžeme konstatovat, že didaktický aparát čítankové řady nakladatelství Fraus sice zohledňuje vlastní obsah estetickovýchovného pojetí literárního vzdělávání v primární škole zřetelnou dominancí otázek/úkolů a námětů k činnostem zaměřených na př́mou práci žáků s uměleckým textem. Ten však nepojímá $\mathrm{v}$ jeho celistvé struktuře všechny vzájemně provázané roviny uměleckého díla, jelikož v didaktickém aparátu čítanek výrazně dominují otázky zaměřené na téma a smysl čteného na úkor ostatních oblastí struktury uměleckého textu (absentuje zejména oblast žánrového zařazení textu, problematika vypravěče a intertextovosti, jak uvádíme v podkapitole Kategorie Text této práce).

Dále jsme zjistili, že didaktický aparát čítankové řady z nakladatelství SPN vykazuje v rámci všech zkoumaných čítanek vyšší míru zastoupení otázek/ úkolů a námětů $\mathrm{k}$ činnostem vztahujícím se $\mathrm{k}$ uměleckému textu a jeho jednotlivým oblastem (40\%). Tato hodnota je však do velké míry ovlivněna dominantním zastoupením podkategorií Téma (15\%) a Smysl $(14 \%)$ v čítankách pro 4. a 5. ročník. V ostatních čítankách z nakladatelství SPN je míra zastoupení otázek/úkolů a námětů k činnostem vztahujícím se k př́ímé práci žáků s rovinami uměleckého textu nízká.

Co se týká míry zastoupení jednotlivých oblastí struktury uměleckého textu, vykazují čítanky nakladatelství SPN shodné rysy s čítankami nakladatelství Fraus v nízkém zastoupení oblastí žánrového zařazení textu, problematiky

14 Pro podkategorii T6 Smysl jsme zjistili statisticky významně vyšší zastoupení otázek/ úkolů/námětů k činnostem u čítanky pro 5. ročník $(\mathrm{z}=2,78)$ a nižší u čítanky pro 2. ročník $(\mathrm{z}=-4,01)$. Podkategorie T5 Téma je významně více zastoupena v čítankách pro 4. ročník $(\mathrm{z}=4,25)$ a 5 . ročník $(\mathrm{z}=2,11)$, méně u čítanky pro 2 . ročník $(\mathrm{z}=-4,55)$. Pro podkategorii T2 Žánr jsme zjistili významně vyšší zastoupení u čítanky pro 5. ročník $(\mathrm{z}=3,78)$ a nižší u čítanek pro 2. ročník $(\mathrm{z}=-2,75)$ a 4 . ročník $(\mathrm{z}=-2)$. Podkategorie T1 Jazyk a styl je statisticky významně více zastoupena u čítanky pro 3. ročník $(\mathrm{z}=2,48)$ a méně u čítanky pro 4. ročník $(z=-2,22)$. 
vypravěče a intertextovosti a dominanci textových oblastí týkajících se tematiky a smyslu čteného textu. Čítanková řada nakladatelství SPN prokazuje rozmanitější zastoupení jednotlivých oblastí struktury uměleckého textu ve svém didaktickém aparátu než čítanková řada nakladatelství Fraus, k vlastnímu obsahu literárního vzdělávání - uměleckému textu - se však její didaktický aparát vztahuje pouze v malé míře.

0 zastoupení přímé práce $s$ textem ve srovnání didaktického aparátu jednotlivých ročníků všech zkoumaných čítanek můžeme konstatovat, že didaktický aparát čítanek pro 4. ročník poskytuje žákům největší př́ležitost př́mé práce s textem (Fraus 80 \%; SPN 49 \%). Tyto čítanky (i přes uvedené nerozmanité zastoupení struktury jednotlivých oblastí uměleckého textu) nejvýrazněji směřují k naplnění estetickovýchovného pojetí literárního vzdělávání v primární škole ve svém didaktickém aparátu. Výraznou př́íležitost $\mathrm{k}$ rozvoji komunikačně pojaté literární výchovy rovněž poskytuje na umělecký text zaměřený didaktický aparát čítanky pro 5. a 3. ročník z nakladatelství Fraus (76\%; 69 \%). Didaktický aparát čítanky pro 5. ročník z nakladatelství SPN přímou práci žáků s uměleckým textem nepreferuje (43\%). Překvapivým zjištěním našeho výzkumu bylo, že čítanky určené žákům nejnižších ročníků - konkrétně čítanka pro 3. ročník z nakladatelství SPN (40 \%) a obě analyzované čítanky pro 2. ročník (Fraus $40 \%$; SPN $20 \%$ ) ve svém didaktickém aparátu přímou práci s uměleckým textem zohledňují nejméně ze všech analyzovaných čítanek.

- Do jaké míry jsou v didaktickém aparátu čítanek zastoupeny otázky/úkoly a náměty $k$ činnostem směrující $k$ mezipredmětovému propojení literární výchovy s ostatními školními predměty?

Zjistili jsme, že zastoupení otázek, úkolů a námětů k činnostem vztahujících se k uměleckému textu, jejichž obsahy směřují k mezioborovému propojení literární výchovy s ostatními školními předměty, je v rámci všech analyzovaných čítanek průměrné (18\%) a nerozmanité, jelikož zde výrazně dominuje mezipředmětové propojení literární výchovy s českým jazykem (65 \%). Vyšší míry zastoupení mezipředmětových vazeb shodně dosahují didaktické aparáty čítanek ve spojení literární výchovy a našeho světa a literární výchovy a výtvarné výchovy. K provázanosti tematiky uměleckého textu s obsahy ostatních školních předmětů se didaktický aparát čítanek váže jen minimálně, popřípadě vůbec. 
Co se týká komparace analyzovaných čítankových řad, v propojení literární výchovy s ostatními školními předměty výrazně dominují čítanky nakladatelství SPN, přičemž rozdíly v zastoupení jednotlivých podkategorií v didaktickém aparátu čítanek nakladatelství SPN byly významně vyšší než v didaktickém aparátu čítanek nakladatelství Fraus v podkategoriích KS2 Literární výchova - matematika $\left(\chi^{2}=29,59 ; \mathrm{p}<0,001\right)$, KS4 Literární výchova - hudební výchova $\left(\chi^{2}=23,69 ; \mathrm{p}<0,001\right)$ a KS5 Literární výchova - výtvarná výchova $\left(\chi^{2}=16,78 ; p<0,001\right)$.

V jednotlivých čítankách se pak mezioborovému propojení literární výchovy s ostatními školními předměty nejvýrazněji věnuje čítanka pro 5. ročník z nakladatelství SPN (46\%), nejméně čítanka pro 3. ročník z nakladatelství Fraus $(18,3 \%)$.

- Do jaké míry se didaktický aparát čítanek orientuje na literárně-teoretické, biografické a historické kontexty, které nesouvisejí s textem umělecké povahy zařazeným do čítanky?

Bylo zjištěno, že zaměření obsahů otázek/úkolů a námětů na literární historii a terminologii bez př́mé souvislosti $s$ uměleckým textem zařazeným do čítanky se $\mathrm{v}$ didaktickém aparátu zkoumaných čítanek objevuje velmi zřídka (4\%), s vyšší mírou zastoupení u čítanek z nakladatelství SPN než u čítanek z nakladatelství Fraus. V jednotlivých čítankách jsou patrné značné rozdíly v zastoupení oblastí mimoestetického kontextu, přičemž u čítanek nakladatelství SPN dominují oblasti týkající se biografie a tvorby básníků a spisovatelů, u čítanek z nakladatelství Fraus převažuje vyšší míra zastoupení oblasti literární terminologie nesouvisející s textem umělecké povahy zařazeným do čítanky.

- Do jaké míry jsou $v$ didaktickém aparátu čítanek obsaženy otázky, úkoly a náměty $k$ činnostem sloužící $k$ ilustraci neliterárních školních předmětů?

Zjistili jsme, že míra zastoupení otázek/úkolů a námětů k činnostem, jejichž zaměření se týká vzdělávacích obsahů neliterárních školních předmětů, dosahuje v didaktickém aparátu všech zkoumaných čítanek průměrných hodnot (19 \%). Analýza ukázala, že v didaktickém aparátu zkoumaných čítanek dominují vyrovnané hodnoty zastoupení otázek/úkolů a námětů $\mathrm{k}$ činnostem vztahujících se ke školním předmětům český jazyk (4\%) a náš svět (4\%) společně se zaměřením na dosavadní životní zkušenosti žáka (3\%). Ostatní vyučovací předměty jsou zastoupeny v malé míre, popřípadě absentují. 
Míra zastoupení otázek/úkolů a námětů k činnostem, které ve svém obsahovém zaměření nezohledňují vztah $\mathrm{k}$ uměleckému textu uvedenému $\mathrm{v}$ čítance, ale zaměřují se na různé oblasti vzdělávacích obsahů neliterárních školních předmětů a reálií ze života žáka, je výrazně vyšší u čítanek z nakladatelství SPN než u čítanek z nakladatelství Fraus, přičemž nejvyšší míra zastoupení byla zjištěna u čítanky pro 2. ročník z nakladatelství SPN (54 \%), nejnižší u čítanky pro 5. ročník z nakladatelství Fraus (6 \%).

\section{Závěrem}

V předloženém výzkumu nás zajímalo, do jaké míry podporuje didaktický aparát čítanek pro primární školu př́mou práci žáků s uměleckým textem. Tuto problematiku jsme pojali jako výzkumný problém, k jehož analyzování jsme vytvořili původní kategoriální systém sloužící k posuzování povahy zadání otázek, úkolů a námětů k činnostem zařazených do čítanek podle toho, zda se vztahují k přímé práci žáků s uměleckým textem. Kategoriální systém považujeme za př́nosný z metodologického hlediska, jelikož jej lze použít jako jeden z možných diagnostických nástrojů pro evaluaci čítanek (v adaptované podobě nejen pro primární školu), jako metodickou oporu pro pedagogickou praxi při učitelově koncipování hodin literární výchovy zaměřených na přímou práci žáků s textem či mezioborové přesahy nebo jako podklad či nástroj zpětné vazby při tvorbě čítanek a metodických příruček zaměřených na přímou práci žáků s uměleckým textem.

Výsledky analýzy poukázaly na některé společné tendence a významné rozdíly v pojetí didaktického aparátu čítanek pro primární školu. Jejich zhodnocení a interpretace nabídla možné podněty pro další směřování čítanek v duchu estetickovýchovného zaměření školní literární výchovy. Za nejzávažnější zjištění provedeného výzkumu považujeme výrazné rozdíly v zastoupení př́mé práce $\mathrm{s}$ uměleckým textem $\mathrm{v}$ didaktickém aparátu čítanek mezi jednotlivými ročníky. Zatímco didaktický aparát čítanek pro 4. ročník zohledňuje umělecký text nejvíce, $v$ čítankách pro 2. ročník je práce s uměleckým textem zohledňována minimálně, a to zejména ve prospěch kurikulem preferovaných mezioborových přesahů. Tato disproporce $v$ naplňování př́ímé práce $\mathrm{s}$ uměleckým textem vede k otázkám týkajícím se směřování literárního vzdělávání v duchu rozvoje literární kompetence a literární gramotnosti žáků - tedy z požadavků na rozvoj kultivovaného čtenářství vycházejí primárně z žákova porozumění čtenému textu. Předpoklad tohoto procesu 
spatřujeme ve vytvoření pozitivního vztahu žáků k textům slovesného umění prostřednictvím zážitku z četby nebo poslechu a jeho sdílení již od nejútlejšího věku. Proto považujeme za silně znevýhodňující faktor (zvláště u čítanek pro nejmladší žáky - začínající čtenáře) směřování didaktického aparátu čítanek k mimotextové realitě odklánějící se od literárních cílů.

Další významné zjištění pro celý soubor čítanek spatřujeme v nerozmanitém a izolovaném zastoupení jednotlivých oblastí uměleckého textu, jehož osobitý charakter spočívá ve vzájemném prolínání všech textových rovin, které se navzájem dotvářejí, a teprve dohromady dávají nahlédnout do smyslu textu.

S ohledem na teoretické poznatky, předcházející výzkumy a výsledky naší analýzy bychom rádi předložili některé návrhy týkající se tvorby čítanek, což považujeme za praktický přínos předkládané práce vedoucí ke zkvalitnění čítanek ve prospěch přímé práce žáků s texty umělecké literatury. Chtěli bychom předeslat, že si uvědomujeme, jak náročný je proces tvorby učebnic (srov. Mikk, 2007, s. 12), který vyžaduje množství odborných, praktických i osobnostních kompetencí jejich tvůrců, a v neposlední řadě, jak uvádí Hník (2010, s. 14), „vlastní učitelskou i životní zkušenost“. Zároveň se ztotožňujeme s názorem Peškové (2012, s. 108), aby tvorba učebnic „vycházela jak z poznatků ve vědě a výzkumu, tak ze zpětných vazeb o tom, jak učebnice fungují v reálné školní edukaci“.

Pro koncipování didaktického aparátu čítanek považujeme za nejpříhodnější vycházet $\mathrm{z}$ charakteru daného uměleckého textu, ke kterému se má didaktický aparát vztahovat. Samotné rozpoznání osobitých rysů uměleckého textu již anticipuje pestrost a variabilitu námětů tvořících podoby zadání didaktického aparátu čítanek a nabízí tak i znevýhodněným žákům (za něž považujeme nejen žáky se specifickými vzdělávacími potřebami a žáky, pro něž není čeština mateřským jazykem, ale i žáky z čtenářsky nepodnětného rodinného prostředí) mnohotvárný, komunikačně otevřený prostor ke specifickému vnímání textu, jeho interpretaci a komunikaci. Různé podoby zadání didaktického aparátu čítanek otázek (ve smyslu kladení otázek otevřených, polootevřených i uzavřených) a jejich vhodné rozmístění (nejen za text, ale i před text jako uvedení do dané oblasti či do průběhu textu - např́klad při předvídání děje) pak může přirozeně podněcovat spontánní tvořivou práci žáků s uměleckým textem, a tedy přirozeně motivovat k mimoškolní četbě. 
Požadovaná rozmanitost didaktického aparátu čítanek by se však měla týkat všech vyváženě zastoupených rovin literárního díla (nikoliv pouze jednotlivých oblastí týkajících se např. tematiky či jazyka čteného textu), aby žáci měli možnost získat nejrůznější podněty pro vnímání textu v jeho komplexnosti a provázanosti. Domníváme se, že přímá práce $s$ textem, zvláště pak s jeho extensionální dimenzí, již je možné zažít pouze v přímém aktu čtení či poslechu, je určujícím faktorem obsahového naplnění didaktického aparátu čítanek vedoucím k spontánní literární tvořivosti žákủ, ke sdílení estetických zážitků, otevřené komunikaci a motivaci k celoživotnímu čtenářství.

Na obsahové zaměření didaktického aparátu čítanek směřující k neliterárním aspektům textu čili k ilustraci obsahů ostatních školních předmětů nerezignujeme, naopak, domníváme se, že zejména ve výuce jazyků či v ostatních estetických výchovách jsou mezioborové přesahy vložené do didaktického aparátu čítanek žádoucí. Upřednostňování mimoestetických přesahů na úkor uměleckých kvalit textu a jeho primárně estetického ladění v didaktickém aparátu čítanek však nepovažujeme za smysluplné naplňování potenciálu školní literární výchovy.

\section{Literatura}

Bubeníčková, P., Čuřín, M., Izáková, E., Markoš, M., Vaníčková, V., \& Zachová, A. (2012). Rozměry čtenářství. Hradec Králové: Gaudeamus.

Campbel, J. R., \& Mullis, I. V. S. (Eds.). (2001). Framework and specificationsfor PIRLS Assesment 2001. Chestnut Hill, MA: TIMSS \& PIRLS International Study Center, Boston College.

Carley, K. (1993). Coding choices for textual analysis: A comparison of content analysis and map analysis. Sociological Methodology, 23(1), 75-126.

Červenka, M. (2003). Fikční světy lyriky. Praha: Paseka.

Doležel, L. (2000). Kapitoly z dějin strukturální poetiky. Od Aristotela až k Pražské škole. Brno: Host.

Doležel, L. (2003). Heterocosmica: Fikce a možné světy. Praha: Karolinum.

Doležel, L. (2004). Identita literárního díla. Praha: Ústav pro českou literaturu AV ČR.

Ďoubalová, K., Hník, O., Homolová, K., Krabsová, V., Lomenčík, J., \& Wildová, R. (2012). Čtenářská gramotnost a podpora jejího rozvoje ve škole. Praha: Univerzita Karlova v Praze, Pedagogická fakulta.

Gejgušová, I. (2011). Mimočítanková četba a cíle literární výchovy na základní škole: Podíl doporučené četby na dětském čtenářství. Ostrava: Pedagogická fakulta Ostravské univerzity $\mathrm{v}$ Ostravě.

Germušková, M. (2003). Literárny text v didaktickej komunikácii. Prešov: Fakulta humanitných a prírodnýchvied prešovské univerzity.

Haman, A. (2012). Literární dílo a soudobá literární věda. Praha: Arsci. 
Helmers, H. (1969). Geschichte des deutschen Lesebuchs in Grundzügen. Stuttgart: Klett.

Hník, O. (2010). Literární výchova: reflexe v oborové didaktice. In E. Príhodová (Ed.), Oborová didaktika v príprave a d'alšom vzdělávání učitel materinského jazyka a literatury (s. 152-158). Ružomberok: Filozofická fakulta Katolickej univerzity v Ružomberku.

Hník, O. (2011). Čtenářsky pojatá literární výchova a její klíčové kategorie. In R. Wildová (Ed.), Rozvoj čtenářrských kompetencí v prostředí inkluzivní školy. Praha: Pedagogická fakulta Univerzity Karlovy v Praze.

Hoppe, H. (2011). Aufgaben im Schulbuch. In E. Matthes, \& S. Schütze (Eds.), Aufgaben im Schulbuch (s. 211-221). Bad Heilbrunn: Julius Klinkhardt.

Hrabák, J. (1977). Poetika. Praha: Československý spisovatel.

Chráska, M. (2007). Metody pedagogického výzkumu: základy kvantitativního výzkumu. Praha: Grada.

Janoušek, P. (2009). Didaktici všech českých zemí, spojte se! Tvar, 9(7),10-11.

Komenský, J. A. (1930). Jana Amosa Komenského Didaktika velká. Praha: Dědictví Komenského.

Lavičková, H. (2012). Analýza kvality čítanek pro primární školu: od vymezení pojmů k výzkumnému nástroji. In T. Janík, \& K. Pešková, et al., Školní vzdělávání: podmínky, kurikulum, aktéři, procesy, výsledky (s. 116-127). Brno: Masarykova univerzita.

Lavičková, H. (2013). Kvalita čítanek pro primární školu: finalizace výzkumného nástroje. In T. Janík, \& K. Pešková, et al., Školní vzdělávání: od podmínek $k$ výsledkům (s. 59-76). Brno: Masarykova univerzita.

Lederbuchová, L. (2001). Literatura ve škole jako učivo, nebo jako literatura? Ergo, 3(4), 73-84.

Lederbuchová, L. (2003-2004). K čítankám na 2. stupni ZŠ (se zaměřením na čítanky pro 6. ročník) I. Český jazyk a literatura, 54(1), 1-7.

Lederbuchová, L. (2003-2004b). K čítankám na 2. stupni ZŠ (se zaměřením na čítanky pro 6. roč.) II. Český jazyk a literatura, 54(2), 53-56.

Lederbuchová, L. (2008). Čtenářská zkušenost žáka jako didaktický prekoncept. In J. Zítková (Ed.), Komunikace a výuka českého jazyka a literatury (s. 81-88). Brno: Masarykova univerzita.

Lesňák, R. (1982). Literárne dielo a čitatel'. Bratislava: Slovenský spisovatel'.

Ligoš, M. (2009). Dynamika slova a obrazu vo vyučování materinského jazyka a literatúry. In R. Šink (Ed.), 12. kulatý stůl - Komunikace s dětmi a mládeží - spojující i rozdělující: sborník př́spěvků z konference s mezinárodní účastí (s. 44-52). Ostrava: Pedagogická fakulta Ostravské univerzity v Ostravě.

Liptáková, L. (Ed.). (2011). Integrovaná didaktika slovenského jazyka a literatury preprimárne vzdelávanie. Prešov: Pedagogická fakulta Prešovské univerzity v Prešove.

Macura, V., \& Jedličková, A. (Eds.). (2012). Průvodce po světové literární teorii 20. století. Brno: Host.

Mikk, J. (2007). Učebnice: Budoucnost národa. In J. Maňák \& P. Knecht (Eds.), Hodnocení učebnic (s. 11-23). Brno: Paido.

Mukařovský, J. (1966). Studie z estetiky. Praha: Odeon.

Müller, R., \& Šidák, P. (Eds.). (2012). Slovník novější literární teorie. Academia.

Pešková, K. (2012). Vizuální prostředky pro výuku reálií v učebnicích němčiny. Brno: Masarykova univerzita.

Peterka, J. (2009). Teorie literatury pro učitele. Praha: Mercury Music \& Entertainment. 
Plch, J. (1981). O výchově slovesným uměním. Praha: SPN.

Pokorná, I. (2003). Didaktická vybavenost čítanek pro 6. ročník základní školy. Český jazyk a literatura, 63(4), 161-166.

Průcha, J., Walterová, E., \& Mareš, J. (2013). Pedagogický slovník. Praha: Portál.

Rámcový vzdělávací program pro základní vzdělávání. (2007). Praha: VÚP.

Rabušicová, M. (2002). Gramotnost: staré téma v novém pohledu. Brno: Masarykova univerzita, Filozofická fakulta.

Ruebsamen, B., \& Erner, J. (1993). Ist das Lesebuch passe? Ergebnisse einer Umfrage in der Grundschule. Grundschule, 26(12), 57-60.

Slavík, J. (1997). Od výrazu $k$ dialogu ve výchově. Artefiletika. Praha: Univerzita Karlova Karolinum.

Slavík, J. (2001). Umění zážitku, zážitek umění. Praha: Pedagogická fakulta Univerzity Karlovy v Praze.

Slavík, J. (2011). K předmětu didaktik v estetických oborech vzdělávání. Pedagogická orientace, 21(2), 207-225.

Švec, Š. (2009). Metodologie věd o výchově. Brno: Paido.

Vařejková, V. (1998). Literárněvýchovná interpretace uměleckého textu na 1. stupni základní školy. Brno: Masarykova univerzita.

Výzkumný ústav pedagogický (2011). Gramotnosti ve vzdělávání. Praha: VÚP v Praze.

Wilde, D. (2000). Lesebuch als Universalbuch für sämtliche Schulfächer, lesebuchfixierte Phase. Berlin: Freie Universität Berlin.

Zítková, J. (2005). Čítanka jako prostředek kultivace osobnosti žáka primární školy (Disertační práce). Dostupné z https://is.muni.cz/auth/th/789/pedf_d/A-Uvod.doc

\section{Analyzované čítanky}

Čeňková, J., \& Ježková, A. (2010). Čítanka 2 pro základní školy. Praha: SPN.

Čeňková, J., \& Ježková, A. (2010). Čítanka 3 pro základní školy. Praha: SPN.

Čeňková, J., \& Jonák, Z. (2010). Čítanka 5 pro základní školy. Praha: SPN.

Čeňková, J., \& Jonáková, A. (2010). Č́tanka 4 pro základní školy. Praha: SPN.

Šebesta, K., \& Váňová, K. (2008). Čítanka 2. Plzeň: Fraus.

Šebesta, K., \& Váňová, K. (2009). Čítanka 3. Plzeň: Fraus.

Šebesta, K., \& Váňová, K. (2010). Čítanka 4. Plzeň: Fraus.

Šebesta, K., \& Váňová,K. (2011). Čítanka 5. Plzeň: Fraus.

\section{Autorka}

Mgr. Hana Lavičková, Ph.D., Masarykova univerzita, Pedagogická fakulta, Katedra českého jazyka a literatury, Poříčí 7, 60300 Brno, e-mail: lavickova@mail.muni.cz 


\title{
Artistic text in didactic apparatus of reading textbooks for primary schools: Results of an analysis
}

\begin{abstract}
The aim of the study is to present empirical results of a content analysis of didactic apparatus reading books designed for pupils in primary schools in terms of its progress towards the fulfillment of direct pupils work with artistic texts in reading books. In the first part of the study we pointed out the specific role of reading books in developing the concept esthetic-educational school literary education. The second part is devoted to literary theory, literary-didactic and curriculum bases of the research. The third part describes the current state of knowledge in the field of research on reading books. The fourth section presents the research methodology; the research sample included two comprehensive textbook series (in total 8 reading books for $2^{\text {nd }}$ to $5^{\text {th }}$ grade of primary school), consisted of 3450 questions, themes and suggestions for activities for the pupils' work. The fifth part presents the results of research that highlighted some common tendencies and differences between compared reading books. We found that the work of pupils with artistic text (through didactic apparatus included in reading books) is most evident in reading book for $4^{\text {th }}$ grade and least for the $2^{\text {nd }}$ grade of primary school. The results show that the representation of the different areas of artistic text in researched reading books is not various. The didactic apparatus of reading books is dominated by such questions, themes and suggestions for activities that aim at topic and meaning of artistic text. Based on the results presented in the conclusion of the study we offer recommendations for creating reading books.
\end{abstract}

Keywords: artistic text, literary education, primary school, reading textbook, didactic apparatus, content analysis

Lukášová, H., Svatoš, T., \& Majerčíková, J. (2014). Studentské portfolio jako výzkumný prostředek poznání cesty $k$ učitelství: př́spěvek $k$ autoregulaci profesního učení a seberozvoje. Zlín: Univerzita Tomáše Bati.

Monografie se zrodila v přesvědčení, že záměrně a smysluplně vytvářené studentské portfolio, na úrovni jednotlivce i celých skupin studentů, má v sobě zatím nevyužité výzkumné možnosti. Záměrem autorů bylo zmiňovaný předpoklad doložit na několika výzkumných příkladech, a to v návaznosti na dosud známé teoretické poznatky. 